\title{
Semi-empirical parameterization of size-dependent atmospheric nanoparticle growth in continental environments
}

\author{
S. A. K. Häkkinen ${ }^{1}$, H. E. Manninen ${ }^{1,2}$, T. Yli-Juuti ${ }^{1}$, J. Merikanto ${ }^{1}$, M. K. Kajos ${ }^{1}$, T. Nieminen ${ }^{1,3}$, S. D. D'Andrea ${ }^{4,5}$, \\ A. Asmi ${ }^{1}$, J. R. Pierce ${ }^{5,4}$, M. Kulmala ${ }^{1}$, and I. Riipinen ${ }^{6,1}$ \\ ${ }^{1}$ Department of Physics, University of Helsinki, Helsinki, Finland \\ ${ }^{2}$ Institute of Physics, University of Tartu, Tartu, Estonia \\ ${ }^{3}$ Helsinki Institute of Physics, University of Helsinki, Helsinki, Finland \\ ${ }^{4}$ Department of Physics and Atmospheric Science, Dalhousie University, Halifax, Nova Scotia, Canada \\ ${ }^{5}$ Department of Atmospheric Science, Colorado State University, Fort Collins, CO, USA \\ ${ }^{6}$ Department of Applied Environmental Science and Bert Bolin Centre for Climate Research, Stockholm University, \\ Stockholm, Sweden
}

Correspondence to: S. A. K. Häkkinen (silja.hakkinen@helsinki.fi)

Received: 11 March 2013 - Published in Atmos. Chem. Phys. Discuss.: 28 March 2013

Revised: 28 June 2013 - Accepted: 5 July 2013 - Published: 9 August 2013

\begin{abstract}
The capability to accurately yet efficiently represent atmospheric nanoparticle growth by biogenic and anthropogenic secondary organics is a challenge for current atmospheric large-scale models. It is, however, crucial to predict nanoparticle growth accurately in order to reliably estimate the atmospheric cloud condensation nuclei $(\mathrm{CCN})$ concentrations. In this work we introduce a simple semiempirical parameterization for sub- $20 \mathrm{~nm}$ particle growth that distributes secondary organics to the nanoparticles according to their size and is therefore able to reproduce particle growth observed in the atmosphere. The parameterization includes particle growth by sulfuric acid, secondary organics from monoterpene oxidation $\left(\mathrm{SORG}_{\mathrm{MT}}\right)$ and an additional condensable vapor of non-monoterpene organics ("background"). The performance of the proposed parameterization was investigated using ambient data on particle growth rates in three diameter ranges $(1.5-3 \mathrm{~nm}, 3-7 \mathrm{~nm}$ and $7-20 \mathrm{~nm})$. The growth rate data were acquired from particle/air ion number size distribution measurements at six continental sites over Europe. The longest time series of $7 \mathrm{yr}$ (2003-2009) was obtained from a boreal forest site in Hyytiälä, Finland, while about one year of data (20082009) was used for the other stations. The extensive ambient measurements made it possible to test how well the parameterization captures the seasonal cycle observed in sub$20 \mathrm{~nm}$ particle growth and to determine the weighing fac-
\end{abstract}

tors for distributing the $\mathrm{SORG}_{\mathrm{MT}}$ for different sized particles as well as the background mass flux (concentration). Besides the monoterpene oxidation products, background organics with a concentration comparable to $\mathrm{SORG}_{\mathrm{MT}}$, around $6 \times 10^{7} \mathrm{~cm}^{-3}$ (consistent with an additional global SOA yield of $100 \mathrm{Tg} \mathrm{yr}^{-1}$ ) was needed to reproduce the observed nanoparticle growth. Simulations with global models suggest that the "background" could be linked to secondary biogenic organics that are formed in the presence of anthropogenic pollution.

\section{Introduction}

Atmospheric aerosol particles affect our life multiple ways - they can cause adverse health effects (Nel, 2005), reduce visibility (Cabada et al., 2004), and affect Earth's climate. Aerosols influence climate directly by scattering and absorbing solar radiation (Bohren and Huffman, 1983) and indirectly via cloud formation (Ramanathan et al., 2001). Sufficiently large aerosol particles with dry diameters of around $70 \mathrm{~nm}$ (Dusek et al., 2006) can act as cloud condensation nuclei $(\mathrm{CCN})$ and form cloud droplets. Cloud properties are affected by the composition and concentration of $\mathrm{CCN}$ (Rosenfeld et al., 2008) whereas the concentration of CCN 
depends strongly on the atmospheric aerosol size distribution (Pierce and Adams, 2007).

The formation of new aerosol particles from vapors has been observed frequently in the atmosphere (Kulmala et al., 2004; Kulmala and Kerminen, 2008), and the subsequent growth of the newly formed particles to $\mathrm{CCN}$ sizes is common in many types of continental boundary layers (Kerminen et al., 2012). Atmospheric modeling suggests that new particle formation is an important source of global CCN (Spracklen et al., 2008; Merikanto et al., 2009). However, gaps in our understanding of particle formation and growth processes bring uncertainty to the quantitative estimation of $\mathrm{CCN}$ production from new particle formation (Spracklen et al., 2008; Pierce and Adams, 2009). The growth of freshlyformed nanoparticles by vapor condensation is a major factor determining whether these particles reach sizes where they can act as CCN and influence climate (Kulmala et al., 1998; Kerminen and Kulmala, 2002; Kuang et al., 2009). This growth needs to be represented accurately enough in atmospheric models to yield reliable predictions of the contribution of atmospheric new particle formation to $\mathrm{CCN}$ concentrations (Riipinen et al., 2011).

Ambient and laboratory studies have shown that sulfuric acid participates in the first steps of new particle formation (Weber et al., 1996; Sihto et al., 2006; Riipinen et al., 2007; Kuang et al., 2008; Sipilä et al., 2010; Vehkamäki and Riipinen, 2012; Kulmala et al., 2013), but sulfuric acid condensation is not enough to reproduce particle growth rates observed in the ambient conditions (Kuang et al., 2010; Sipilä et al., 2010; Pierce et al., 2011, 2012; Riipinen et al., 2011, 2012; Kulmala et al., 2013). Therefore other compounds, e.g., organics or ammonia/amines, are expected to be important in the early growth of freshly nucleated particles (O'Dowd et al., 2002; Smith et al., 2005, 2008; Pierce et al., 2011; Riipinen et al, 2012; Vehkamäki and Riipinen, 2012; Kulmala et al., 2013). Several recent studies point to the importance of organic compounds in growing atmospheric nanoparticles to climatically relevant sizes (e.g., Kulmala et al., 1998; Kuang et al., 2010; Yli-Juuti et al., 2011; Riipinen et al., 2012 and references therein), and capturing this organic contribution has been shown to be important for $\mathrm{CCN}$ predictions on regional scale (Riipinen et al., 2011).

Oxidation of volatile organic compounds (VOCs) and their subsequent condensation to the particulate phase is known to be an important source of atmospheric aerosol mass. The aerosol constituents formed through these oxidation reactions and their subsequent condensation to the particulate phase are called secondary organic aerosol (SOA). Traditionally biogenic VOCs (BVOC), such as monoterpenes (MT) and isoprene, are thought to be the dominant source of atmospheric SOA (e.g., Kanakidou et al, 2005; Hallquist et al., 2009), but recent studies suggest also a notable anthropogenic contribution to SOA formation (Volkamer et al., 2006; Zhang et al., 2007; Heald et al., 2011; Hoyle et a., 2011; Spracklen et al., 2011).
The capability of an SOA component to grow a nanoparticle to $\mathrm{CCN}$-sizes depends on the volatility, i.e., the evaporation tendency, of the compound, as well as the size and composition of the particle (see, e.g., Pierce et al., 2011; Zhang et al., 2012a; Vehkamäki and Riipinen, 2012 and references therein). The contribution of SOA to nanoparticle growth would thus be straightforward to calculate if the identities and volatilities of the organic compounds constituting SOA would be known. This is unfortunately not the case. There are thousands of different organic compounds in the atmosphere and their properties are difficult to constrain (Goldstein and Galbally, 2007; Hallquist et al., 2009); this applies particularly to the compounds with the lowest volatility, which are most likely to grow the smallest particles (e.g., Pierce et al., 2011). The volatility assumed for the SOA in atmospheric models significantly affects the way this condensing material modifies the atmospheric aerosol size distribution (see, e.g., Riipinen et al., 2011; Donahue et al., 2011; Zhang et al., 2012b). Current atmospheric large-scale models differ considerably in the ways they treat the condensation of SOA: some assign the SOA a range of volatilities but assume it to be in thermodynamic equilibrium (Yu and Luo, 2009), while others assume the SOA to be completely nonvolatile (Spracklen et al., 2005a, b; Pierce and Adams, 2009; Makkonen et al., 2012). The former approach tends to underestimate the growth of freshly-formed nanoparticles (and thus their contribution to $\mathrm{CCN}$ ), while the latter is expected to somewhat overpredict it if the total SOA is correctly predicted by the model (Riipinen et al., 2011). While it is possible to combine both thermodynamic and kinetic approaches (given that the saturation vapor pressures of the SOA components are known; see, e.g., Pierce et al., 2011), such detailed descriptions of aerosol dynamics are often not computationally feasible in global models. Approaches that capture the contribution of SOA to atmospheric nanoparticle growth in a simple yet physically and chemically reasonable manner are thus needed to improve atmospheric models.

Several recent observations from different field sites suggest that the condensational growth rates of ambient nanoparticles increase with particle size (Hirsikko et al., 2005; Manninen et al., 2010; Yli-Juuti et al., 2011; Kuang et al., 2012). Yli-Juuti et al. (2011) also observed a correlation between monoterpene concentrations and $7-20 \mathrm{~nm}$ particle growth in the boreal forest site of Hyytiälä, Finland, indicating the importance of monoterpene oxidation products in the growth process. Also, a clear seasonal variation in the growth of 3-20 nm particles was observed in Hyytiälä, with highest values during the summer (Dal Maso et al., 2005; Hirsikko et al., 2005; Riipinen et al., 2011; Yli-Juuti et al., 2011). The growth of the smallest sub-3 nm particles in Hyytiälä, on the other hand, has not been observed to show such seasonality (Hirsikko et al., 2005; Yli-Juuti et al., 2011).

In this paper we introduce a simple semi-empirical parameterization for distributing monoterpene-SOA onto aerosol particle populations in a way that it reproduces sub- $20 \mathrm{~nm}$ 


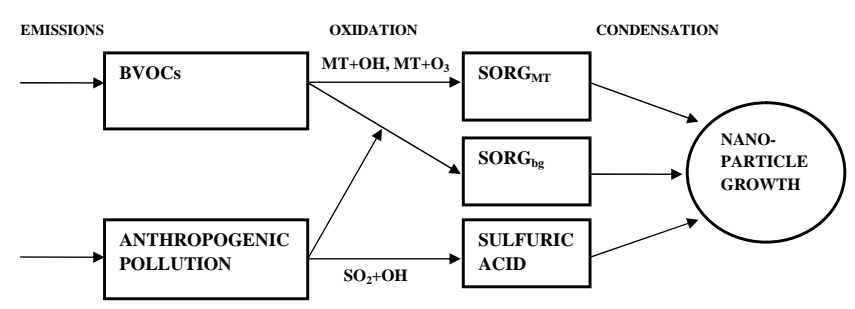

Fig. 1. Schematic of processes leading to nanoparticle growth from the perspective of the parameterization: formation of $\mathrm{SORG}_{\mathrm{MT}}$, SORG $_{\text {bg }}$ and sulfuric acid from biogenic volatile organic compounds (BVOCs) and anthropogenic pollution via atmospheric oxidation and condensation of these vapors onto nanoparticles. Model simulations with GEOS-Chem-TOMAS (Pierce et al., 2013) show that $\mathrm{SORG}_{\mathrm{bg}}$ can be linked to the products of oxidation of biogenic organics in the presence of anthropogenic pollutants (Hoyle et al., 2011; Spracklen et al., 2011).

particle growth. The parameterization is aimed to be simple and thus easily applicable in large-scale atmospheric models. The size-dependent parameterization includes condensational growth of particles by sulfuric acid, secondary organics from monoterpene oxidation $\left(\mathrm{SORG}_{\mathrm{MT}}\right)$ and an additional condensing (presumably organic) species. The parameterization is based on data on atmospheric nanoparticle growth rates from six field sites: the boreal forest site of Hyytiälä (seven years of particle growth data) and a year worth of data from five other European field stations. The sensitivity of the parameterization to the input concentrations of sulfuric acid and monoterpenes (and their oxidation products) is tested, and its implications and potential for use in atmospheric models is discussed.

\section{Materials and methods}

\subsection{Theoretical approach}

\subsubsection{Growth parameterization}

To parameterize the seasonality and size-dependence of nanoparticle growth rates, we express the total condensational mass flux (in $\mathrm{kg} \mathrm{s}^{-1}$ ) onto a particle with diameter $d_{\mathrm{p}}$ as a sum of the mass fluxes of sulfuric acid and organics:

$$
\begin{aligned}
I_{\text {tot }}\left(d_{\mathrm{p}}\right)= & I_{\mathrm{SA}}\left(d_{\mathrm{p}}\right)+k_{\mathrm{MT}}\left(d_{\mathrm{p}}\right) \times I_{\text {SORG, MT }}\left(d_{\mathrm{p}}\right) \\
& +k_{\mathrm{bg}}\left(d_{\mathrm{p}}\right) \times I_{\text {SORG, } \mathrm{bg}}\left(d_{\mathrm{p}}\right),
\end{aligned}
$$

where $I_{\mathrm{SA}}$ is the mass flux caused by sulfuric acid, $I_{\mathrm{SORG}}$ MT is the maximum mass flux by monoterpene first-order oxidation products (denoted as $\mathrm{SORG} \mathrm{MT}_{\mathrm{MT}}$ ), and $I_{\mathrm{SORG}}$,g is the mass flux from other condensable compounds, presumably organics that have not originated from monoterpene oxidation and do not have a seasonal dependence (denoted as $\left.\mathrm{SORG}_{\mathrm{bg}}\right) . k_{\mathrm{MT}}\left(d_{\mathrm{p}}\right)$ and $k_{\mathrm{bg}}\left(d_{\mathrm{p}}\right)$ are weighing factors describing the fractions of $I_{\mathrm{SORG}}$ MT and $I_{\mathrm{SORG}}$ bg that condense onto nanoparticles having diameter $d_{\mathrm{p}}$, and have values between 0 and 1 . Figure 1 illustrates the processes that are accounted for in our analysis: formation of condensable vapors and their condensation onto nanoparticles. Oxidation products of atmospheric isoprene - another important source of SOA - were not explicitly accounted for to keep the parameterization as simple as possible, particularly as there are no clear indications of the importance of isoprene SOA in growing nanoparticles.

One of the aims of this work is to present a semi-empirical approach that is usable in large-scale models, and thus Eq. (1) is a highly simplified representation of the reality and contains several assumptions. First, $I_{\mathrm{SA}}, I_{\mathrm{SORG}} \mathrm{MT}$ and $I_{\mathrm{SORG}}$, bg are calculated assuming totally non-volatile vapors, which is certainly an approximation but in line with the way that many global models treat the condensation of sulfuric acid and organics onto nanoparticles (e.g., Spracklen et al., 2005a, b; Pierce and Adams, 2009). For sulfuric acid this assumption is probably reasonable, as its saturation vapor pressure is known to be extremely low in atmospheric conditions (see, e.g., Kulmala and Laaksonen, 1990). For organic species with varying volatilities, this assumption may cause problems (Pierce et al., 2011), as small particles reach equilibrium more quickly than large particles (due to Kelvin effect and the larger surface-area/volume ratio in small particles); thus, the condensable fraction of SORG $\mathrm{MT}_{\mathrm{T}}$ as well as $\mathrm{SORG}_{\mathrm{bg}}$ can depend strongly on particle size. This effect is indirectly taken into account with the $k$ values in Eq. (1). Furthermore, $I_{\text {SORG, MT }}$ is calculated based on the first-order oxidation products of monoterpenes and thus represents the maximum possible mass flux of $\mathrm{SORG}_{\mathrm{MT}}$ from the firststage oxidation. This assumption as well is in line with what many of the global models assume. Another key assumption is the presence of the "background organics" mass flux $I_{\mathrm{SORG}}$, bg, which is constant throughout the year and represents all the condensable material that is not sulfuric acid or $\mathrm{SORG}_{\mathrm{MT}}$ (or at least not correlated with them). There are several hints pointing to the importance of the additional mass flux in Eq. (1). It is clear that not all condensable organics originate from or correlate with monoterpenes (Spracklen et al., 2011). While BVOCs are probably the most important source of SOA in continental environments, there are also anthropogenic impacts on SOA formation (see, e.g., Hoyle et al., 2011 and references therein). For instance, Spracklen et al. (2011) found that the SOA mass estimated using traditional SOA sources (i.e., monoterpenes, isoprene, biomass burning and the aging of primary organic aerosol) was low compared to ambient observations, and a large additional SOA source - correlated with anthropogenic CO sources was needed to explain the observations. $I_{\text {SORG, bg }}$ could represent this "extra SOA". We will show that this type of additional contribution is needed to reproduce the observed growth rates of atmospheric nanoparticles.

Mass fluxes $I_{\mathrm{tot}}, I_{\mathrm{SA}}$ and $I_{\mathrm{SORG}}$ MT in Eq. (1) were determined using ambient observations complemented with data 
Table 1. Values for parameters used in this study for surrounding air, for condensable vapors (sulfuric acid and organics $\left(\mathrm{SORG}_{\mathrm{MT}}\right.$ and $\left.\mathrm{SORG}_{\mathrm{bg}}\right)$ ) and for particles.

\begin{tabular}{|c|c|}
\hline \multicolumn{2}{|l|}{ Surrounding air } \\
\hline Pressure, $p$ & $1 \operatorname{atm}\left(10^{5} \mathrm{~Pa}\right)$ \\
\hline Temperature, $T$ & $285 \mathrm{~K}$ \\
\hline Molar mass, $M_{\text {air }}$ & $29 \mathrm{~g} \mathrm{~mol}^{-1}$ \\
\hline Dynamic viscosity, $\mu_{\text {air }}$ & $\begin{array}{l}1.8 \times 10^{-5} \mathrm{~kg} \\
\mathrm{~m}^{-1} \mathrm{~s}^{-1}\end{array}$ \\
\hline Mean free path of air molecules, $\lambda_{\text {air }}$ & $64 \mathrm{~nm}$ \\
\hline \multicolumn{2}{|l|}{ Sulfuric acid } \\
\hline Density, $\rho_{\mathrm{SA}}$ & $1.8 \mathrm{~g} \mathrm{~cm}^{-3}$ \\
\hline Molar mass, $M_{\mathrm{SA}}$ & $98 \mathrm{~g} \mathrm{~mol}^{-1}$ \\
\hline Mass of a SA molecule, $m_{\mathrm{SA}}$ & $98 \mathrm{amu}$ \\
\hline Diameter of a SA molecule, $d_{\mathrm{SA}}$ & $0.56 \mathrm{~nm}^{\mathrm{a}}$ \\
\hline Diffusion coefficient, $D_{\mathrm{SA}}$ & $0.1 \mathrm{~cm}^{2} \mathrm{~s}^{-1 \mathrm{~b}}$ \\
\hline Mass accommodation coefficient, $\alpha_{\mathrm{m}, \mathrm{SA}}$ & 1 \\
\hline \multicolumn{2}{|l|}{ Organics } \\
\hline Density, $\rho_{\mathrm{ORG}}$ & $1.5 \mathrm{~g} \mathrm{~cm}^{-3}$ \\
\hline Molar mass, $M_{\mathrm{ORG}}$ & $186 \mathrm{~g} \mathrm{~mol}^{-1}$ \\
\hline Mass of an organic molecule, $m_{\mathrm{ORG}}$ & $186 \mathrm{amu}$ \\
\hline Diameter of an organic molecule, $d_{\mathrm{ORG}}$ & $0.73 \mathrm{~nm}^{\mathrm{a}}$ \\
\hline Diffusion coefficient, $D_{\mathrm{ORG}}$ & $0.1 \mathrm{~cm}^{2} \mathrm{~s}^{-1 \mathrm{~b}}$ \\
\hline Mass accommodation coefficient, $\alpha_{\mathrm{m}}, \mathrm{ORG}$ & 1 \\
\hline \multicolumn{2}{|l|}{ Particle } \\
\hline Density, $\rho_{\mathrm{p}}$ & $1.5 \mathrm{~g} \mathrm{~cm}^{-3}$ \\
\hline
\end{tabular}

from chemical transport model GLOMAP (Global Model of Aerosol Processes, Spracklen et al., 2008). The mass flux (vapor concentration) of the background species, $I_{\text {SORG, bg }}$, and the $k$ values $\left(k_{\mathrm{MT}}\right.$ and $\left.k_{\mathrm{bg}}\right)$ were obtained through leastsquare method by fitting Eq. 1 to the ambient data on sub$20 \mathrm{~nm}$ particle growth. Above $20 \mathrm{~nm}$ the $\mathrm{SORG}_{\mathrm{MT}}$ was assumed to condense kinetically, i.e., assuming no evaporation from the particles, and thus a weighing factor $\left(k_{\mathrm{MT}}\right)$ of unity. Also, for the "background", the $k_{\mathrm{bg}}$ for $7-20 \mathrm{~nm}$ size range and above was assumed unity. The details of the fitting procedure are outlined in the following sections.

\subsubsection{Mass fluxes}

The condensation onto atmospheric nanoparticles is observed as an increase in their size, and is often quantified with the diameter growth rate (GR, in $\mathrm{m} \mathrm{s}^{-1}$ or $\mathrm{nm} \mathrm{h}^{-1}$ ). The relation between GR and $I_{\text {tot }}$ for particles with diameter $d_{\mathrm{p}}$ and density $\rho_{\mathrm{p}}$ (see Table 1 ) is

$I_{\mathrm{tot}}\left(d_{\mathrm{p}}\right)=\frac{1}{2} \pi \rho_{\mathrm{p}} d_{\mathrm{p}}^{2} \mathrm{GR}\left(d_{\mathrm{p}}\right)$.

In this study $I_{\text {tot }}$ was obtained using size-dependent particle growth rates (for size ranges $1.5-3 \mathrm{~nm}, 3-7 \mathrm{~nm}, 7-20 \mathrm{~nm}$ ) determined from ambient particle / ion number size distributions (see Sect. 2.2.1). The particle diameters used to represent the three size classes were $2 \mathrm{~nm}, 5 \mathrm{~nm}$ and $14 \mathrm{~nm}$ (midpoints of size bins in $d_{\mathrm{p}}$ space), respectively. We also tested the effect of using the midpoint diameters in $d_{\mathrm{p}}^{2}$ space as the representative diameters, but found no significant sensitivity of the results to this choice.

The mass fluxes of sulfuric acid and $\mathrm{SORG}_{\mathrm{MT}}$ onto nanoparticles were calculated using the approach presented by Lehtinen and Kulmala (2003) (also Nieminen et al., 2010), where the mass flux of a condensable vapor $v\left(\mathrm{~kg} \mathrm{~s}^{-1}\right)$ is written as

$$
I_{\mathrm{v}}\left(d_{\mathrm{p}}\right)=2 \pi\left(d_{\mathrm{v}}+d_{\mathrm{p}}\right)\left(D_{\mathrm{v}}+D_{\mathrm{p}}\left(d_{\mathrm{p}}\right)\right) \beta_{\mathrm{m}}\left(\alpha_{\mathrm{m}}, K n\right) m_{\mathrm{v}} C_{\mathrm{v}},
$$

where $d_{\mathrm{v}}, D_{\mathrm{v}}$ and $m_{\mathrm{v}}$ are the diameter, diffusion coefficient and mass of the vapor molecule, respectively. $D_{\mathrm{p}}$ is the diffusion coefficient of a particle with diameter $d_{\mathrm{p}}$, and $C_{\mathrm{v}}$ is the molecular concentration of the vapor. $\beta_{\mathrm{m}}$ is the correction factor for transition regime mass transfer (Fuchs and Sutugin, 1971):

$\beta_{\mathrm{m}}\left(\alpha_{\mathrm{m}}, K n\right)=\frac{1+K n}{1+\left(0.377+\frac{4}{3 \alpha_{\mathrm{m}}}\right) K n+\frac{4}{3 \alpha_{\mathrm{m}}} K n^{2}}$,

where $\alpha_{\mathrm{m}}$ is the mass accommodation coefficient and $K n$ is the Knudsen number. $K n$ is defined as the following (Lehtinen and Kulmala, 2003):

$K n=\frac{2 \lambda}{d_{\mathrm{v}}+d_{\mathrm{p}}}$,

where $\lambda$ is the mean free path

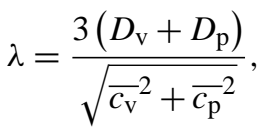

in which $\overline{c_{\mathrm{v}}}$ and $\overline{c_{\mathrm{p}}}$ are the mean thermal speeds of the vapor molecule and the particle, respectively. The equations that were used for determining the mean thermal speeds and diffusion coefficients of molecules and particles are presented in Appendix A. Values for the parameters used in Eqs. (3-6) for determining $I_{\mathrm{SA}}\left(d_{\mathrm{p}}\right)$ and $I_{\mathrm{SORG}}, \mathrm{MT}\left(d_{\mathrm{p}}\right)$ are given in Table 1 . The background vapor was assumed to have the same properties as the $\mathrm{SORG}_{\mathrm{MT}}$. Parameter values were converted to SI-units before substitution to the presented equations.

\subsection{Data sets}

\subsubsection{Particle growth rates}

Sub-20 nm particle growth was investigated in Hyytiälä, Finland $\left(61^{\circ} 50^{\prime} \mathrm{N}, 24^{\circ} 18^{\prime} \mathrm{E}\right.$ ) during 2003-2009 (Yli-Juuti et al., 2011 and Table 2) and at five other sites around Europe during 2008-2009 as part of the EUCAARI (European Integrated project on Aerosol Cloud Climate and Air Quality 
interactions, see Kulmala et al., 2011) project (Manninen et al., 2010 and Table 2). In addition to Hyytiälä, the other European sites were in Melpitz (Germany, $51^{\circ} 32^{\prime} \mathrm{N}, 12^{\circ} 54^{\prime} \mathrm{E}$ ), Hohenpeissenberg (Germany, $47^{\circ} 48^{\prime} \mathrm{N}, 11^{\circ} 00^{\prime} \mathrm{E}$ ), Vavihill (Sweden, $56^{\circ} 01^{\prime} \mathrm{N}, 13^{\circ} 09^{\prime} \mathrm{E}$ ), Finokalia (Greece, $35^{\circ} 20^{\prime} \mathrm{N}$, $25^{\circ} 40^{\prime} \mathrm{E}$ ) and K-puszta (Hungary, $46^{\circ} 58^{\prime} \mathrm{N}, 19^{\circ} 35^{\prime} \mathrm{E}$ ). All the stations were background sites with slightly different characteristics. The environments varied from relatively clean boreal forest site (Hyytiälä, Vesala et al., 1998; Kulmala et al., 2001a; Hari and Kulmala, 2005) to more polluted rural areas (Melpitz, Vavihill and K-Puszta) and from a site with marine influence (Finokalia) to a highaltitude station (Hohenpeissenberg). More detailed information on the EUCAARI measurement stations can be found in Manninen et al. (2010).

Particle growth rates were determined for three diameter ranges, $1.5-3 \mathrm{~nm}, 3-7 \mathrm{~nm}$ and $7-20 \mathrm{~nm}$, from ambient particle / air ion number size distributions measured with an AIS (air ion spectrometer, Mirme et al., 2007) and a NAIS (neutral cluster and air ion spectrometer). For Hyytiälä, also DMPS (differential mobility particle sizer, Aalto et al., 2001) and BSMA (balanced scanning mobility analyzer, Tammet, 2006) data were included in the analysis. DMPS can detect small particles down to $3 \mathrm{~nm}$ sizes and therefore particle growth in the diameter bins of 3-7 nm and 7-20 nm could be determined. Using BSMA data, particle growth in diameter bins $1.5-3 \mathrm{~nm}$ and 3-7 $\mathrm{nm}$ was determined. Growth rates were obtained using an approach described in detail by Hirsikko et al. (2005) in which maximum particle/ion concentration of every size bin was followed through particle growth. More information on the growth rate analysis can be found in Yli-Juuti et al. (2011) for Hyytiälä and in Manninen et al. (2010) for the other EUCAARI sites. Monthly medians of the GR values were used for all further analysis since they are expected to describe well the average growth process of newly formed particles. Monthly GRs could not be determined for each month for each station due to the small amount of data (around one year of observations) for the sites except for Hyytiälä. However, all the stations had at least six months of GR data (Hyytiälä 12 months, corresponding to total 421 GR data points (new particle formation days); Melpitz 6 months and 30 data points; Hohenpeissenberg 9 months and 17 data points; Vavihill 7 months and 22 data points; Finokalia 9 months and 17 data points; and K-puszta 11 months and 68 data points).

\subsubsection{Concentration of sulfuric acid}

To investigate the sensitivity of our approach to the gas phase concentrations of sulfuric acid $\left(C_{\mathrm{SA}}\right)$, we tested two different approaches for estimating $C_{\mathrm{SA}}$ in Hyytiälä: one using GLOMAP (Spracklen et al., 2005a, b), and the other a sulfuric acid proxy presented by Petäjä et al. (2009) (see Table 2)
Table 2. The data sets (monthly medians) used for fitting Eq. 1. Nanoparticle diameter growth rates (GR), concentrations of sulfuric acid $\left(C_{\mathrm{SA}}\right)$ and monoterpenes $\left(C_{\mathrm{MT}}\right)$. The GR data sets are the same as those used by Yli-Juuti et al. (2011) and Manninen et al. (2010). See text for details.

\begin{tabular}{lll}
\hline Data set & Hyytiälä & $\begin{array}{l}\text { Other European } \\
\text { sites }\end{array}$ \\
\hline GR (NAIS/AIS) & $2003-2007$ & $2008-2009$ \\
GR (BSMA) & $2003-2009$ & - \\
GR (DMPS) & $2003-2009$ & - \\
$C_{\text {SA }}$ Petäjä et al. (2009) & $2003-2007$ & - \\
$C_{\mathrm{SA}}$ (GLOMAP) & 2008 & 2008 \\
$C_{\mathrm{MT}}$ Lappalainen & $2003-2009$ & - \\
et al. (2009) & & \\
$C_{\mathrm{MT}}$ (PTR-MS) & $2007-2009$ & - \\
$C_{\mathrm{MT}}$ (GLOMAP) & 2008 & 2008 \\
\hline
\end{tabular}

expressed as

$C_{\mathrm{SA}}=k_{\mathrm{SA}} \frac{C_{\mathrm{SO}_{2}} \times \mathrm{UVB}}{\mathrm{CS}}$,

where $k_{\mathrm{SA}}=8.4 \times 10^{-7} \times \mathrm{UVB}^{-0.68} \mathrm{~m}^{2} \mathrm{~W}^{-1} \mathrm{~s}^{-1}, C_{\mathrm{SO}_{2}}$ is the concentration of $\mathrm{SO}_{2}$, UVB is the intensity of ultraviolet radiation, and CS is the condensation sink for sulfuric acid molecules calculated from the particle number size distribution (DMPS) data (see, e.g., Kulmala et al., 2001b). For the other European stations, sulfuric acid concentrations were obtained from GLOMAP.

\subsubsection{Concentration of SORG}

To test the robustness of our approach with respect to variations in the concentrations of the monoterpenes and their oxidation products, three different sources of data were used for monoterpene concentrations in Hyytiälä: GLOMAP simulations (Spracklen et al., 2006) for the year 2008 using the GEIA database based on MEGAN (Model of Emissions of Gases and Aerosols from Nature, Guenther et al., 1995) for monoterpene emissions, observations with the PTR-MS (Proton Mass Transfer Mass Spectrometer, Lindinger et al., 1998) that was operating during 2007-2009, and a semiempirical parameterization for monoterpene concentrations based on ambient temperatures (Lappalainen et al., 2009; see Table 2). Concentrations of $\mathrm{SORG}_{\mathrm{MT}}$ were then determined using the monoterpene concentrations. This results in altogether five different data sets for the concentrations of SORG $\mathrm{MT}_{\mathrm{MT}}$ in Hyytiälä: one directly from GLOMAP with the complete gas phase chemistry, emissions and losses included; one assuming that condensable $\mathrm{SORG}_{\mathrm{MT}}$ corresponds to $1 \%$ of the monoterpene concentrations from GLOMAP (estimated comparing the concentrations of MT and $\mathrm{SORG}_{\mathrm{MT}}$ from GLOMAP); and three from calculations based on ambient concentrations of $\mathrm{O}_{3}$ and $\mathrm{OH}$ combined 
with monoterpene concentrations from GLOMAP, PTRMS or the temperature-dependent parameterization by Lappalainen et al. (2009). For the other European sites, concentrations of SORG $\mathrm{G}_{\mathrm{MT}}$ were obtained directly from GLOMAP.

Concentrations of SORG $\mathrm{MT}_{\mathrm{MT}}$ can be calculated based on the oxidation rates of monoterpenes with $\mathrm{O}_{3}$ and $\mathrm{OH}$-radical, yielding the steady-state concentrations of the first-order oxidation products.

$C_{\mathrm{SORG}, \mathrm{MT}+\mathrm{OH}}=\frac{k_{\mathrm{OH}} \times C_{\mathrm{OH}} \times C_{\mathrm{MT}}}{\mathrm{CS}}$ and

$C_{\mathrm{SORG}, \mathrm{MT}+\mathrm{O}_{3}}=\frac{k_{\mathrm{O}_{3}} \times C_{\mathrm{O}_{3}} \times C_{\mathrm{MT}}}{\mathrm{CS}}$,

where $\quad k_{\mathrm{OH}}=7.5 \times 10^{-11} \mathrm{~cm}^{3} \mathrm{~mol}^{-1} \mathrm{~s}^{-1} \quad$ and $\quad k_{\mathrm{O}_{3}}=$ $1.4 \times 10^{-17} \mathrm{~cm}^{3} \mathrm{~mol}^{-1} \mathrm{~s}^{-1}$ are rate constants determined specifically for monoterpene oxidation in Hyytiälä (Hakola et al., 2003; Yli-Juuti et al., 2011), $C_{\mathrm{MT}}$ is the monoterpene concentration, and $C_{\mathrm{O}_{3}}$ and $C_{\mathrm{OH}}$ are the concentrations of $\mathrm{O}_{3}$ and $\mathrm{OH}$-radical, respectively. $C_{\mathrm{O}_{3}}$ was obtained from mast measurements in Hyytiälä. $C_{\mathrm{OH}}\left(\mathrm{cm}^{-3}\right)$ was calculated with the parameterization by Petäjä et al. (2009):

$C_{\mathrm{OH}}=\left(\frac{c}{a} \mathrm{GLOB}^{0.3}\right)^{0.52^{-1}}$,

where GLOB is the intensity of global radiation $\left(\mathrm{W} \mathrm{m}^{-2}\right)$, $a=8.6 \times 10^{-10}$ and $c=1.4 \times 10^{-7}$. The total concentration of $\mathrm{SORG}_{\mathrm{MT}}\left(C_{\mathrm{SORG}, \mathrm{MT}}\right)$ was calculated by adding up $C_{\mathrm{SORG}, \mathrm{MT}+\mathrm{OH}}$ and $C_{\mathrm{SORG}, \mathrm{MT}+\mathrm{O}_{3}}$. We thus define $\mathrm{SORG}_{\mathrm{MT}}$ as the steady-state concentration of the monoterpene firstorder oxidation products, and assume that the growing nanoparticles do not contribute significantly to the condensation sink CS. This is a reasonable assumption for most atmospheric background sites.

Only daytime values (09:00-15:00 LT) of sulfuric acid and $\mathrm{SORG}_{\mathrm{MT}}$ concentrations were included in the analysis to represent the conditions during particle formation events that usually occur during day (Kulmala et al., 2004; Yli-Juuti et al., 2011). For the parameterization analysis, monthly median vapor daytime concentrations were used. Due to good data coverage for sulfuric acid, daytime concentrations during new particle formation days were used, whereas for $\mathrm{SORG}_{\mathrm{MT}}$, daytime concentrations of all the available data (including days with observed particle formation as well as days when no new particles were formed) were used.

\subsection{Fitting to ambient data}

Size-dependent weighing factors for distributing the SORG $_{\mathrm{MT}}$ to sub-20 $\mathrm{nm}$ particles ( $k_{\mathrm{MT}}$ values in Eq. 1$)$ and the mass fluxes of additional condensable vapors were estimated by fitting Eq. (1) to the ambient data. Ambient growth rates were used to determine the total mass fluxes in the three diameter bins $(1.5-3 \mathrm{~nm}, 3-7 \mathrm{~nm}$ and $7-20 \mathrm{~nm})$ and the concentrations of sulfuric acid and $\mathrm{SORG}_{\mathrm{MT}}$ were used to determine $I_{\mathrm{SA}}$ and $I_{\mathrm{SORG}}, \mathrm{MT}$. Fitting was done separately for the three size ranges using a least-squares method (function lsqcurvefit in Matlab) with a relative tolerance of $10^{-15}$. The $k_{\mathrm{MT}}$ values for distributing the $\mathrm{SORG}_{\mathrm{MT}}$ were limited between 0 and 1 , and the $I_{\mathrm{SORG}}$ bg was allowed to get any positive values. Based on the $I_{\text {SORG, bg and }}$ corresponding vapor concentrations (obtained using Eq. 3), weighing factors $\left(k_{\mathrm{bg}}\right)$ for distributing the $\mathrm{SORG}_{\mathrm{bg}}$ were estimated assuming that $I_{\text {SORG, bg, 7-20 }}$ is at the kinetic limit. Initial guesses for the $k_{\mathrm{MT}}$ values and/or for the $I_{\mathrm{SORG}}$ bg did not affect the fitting results, i.e., all the fits converged to a unique solution.

The fitting was done using both the Hyytiälä data alone (altogether $7 \mathrm{yr}$ of GR data) and data from the six European sites, including Hyytiälä. The mass flux fits were done to 12 data points. For Hyytiälä, the differently defined concentrations of sulfuric acid and $\mathrm{SORG}_{\mathrm{MT}}$ were used to test the performance of the parameterization and to test its sensitivity to the input data. The EUCAARI data were used to obtain parameterization with weighing factors, $k_{\mathrm{MT}}$ and $k_{\mathrm{bg}}$, and background concentration, $C_{\mathrm{SORG}}$, bg (corresponding $I_{\text {SORG, bg, } 7-20}$ ), representative of the sub- $20 \mathrm{~nm}$ particle growth on a broader continental scale.

\section{Results}

\subsection{Growth parameterization using seven years of data from Hyytiälä}

\subsubsection{Seasonal variation of $S_{O R G}$ at and sulfuric acid concentrations}

Figure 2 illustrates monthly medians of the concentrations of SORG $_{M T}$ and sulfuric acid. The highest sulfuric acid concentrations were observed during springtime, and in general the concentrations of sulfuric acid were lower than those of $\mathrm{SORG}_{\mathrm{MT}}$. The two approaches for obtaining the sulfuric acid concentrations (GLOMAP and the proxy using Eq. 7) gave very similar results, especially taking into account that the GLOMAP data represent a $2.8^{\circ} \times 2.8^{\circ}$ grid box around Hyytiälä, while the proxy calculation is based on in situ data. In the fits for Hyytiälä, the two data sets were combined and the data-amount weighted average concentration was used (gray curve in Fig. 2).

The seasonal pattern in the differently defined concentrations of $\mathrm{SORG}_{\mathrm{MT}}$ was similar - the concentrations peaking in the summer. The seasonal variation in $\mathrm{SORG}_{\mathrm{MT}}$ was less pronounced using the measured monoterpene concentrations or the temperature-dependent measurement-based parameterization, as compared with the values obtained from GLOMAP. The difference between the approaches was greatest during winter. Similar comparison was performed for measured and modeled monoterpene concentrations as well. While the monoterpene concentrations were approximately two orders of magnitude higher than the $\mathrm{SORG}_{\mathrm{MT}}$ 


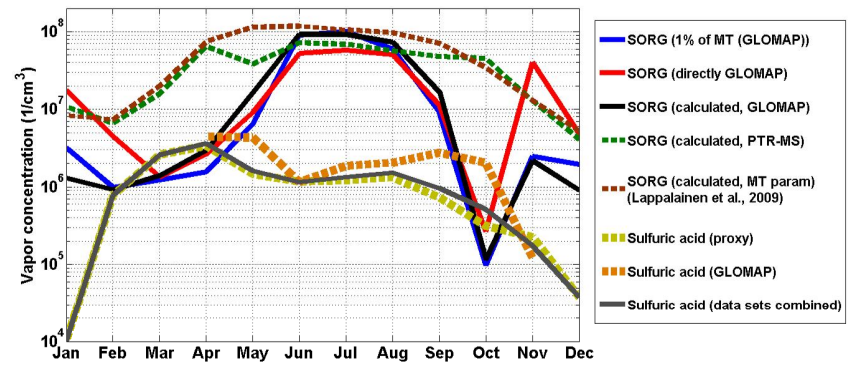

Fig. 2. Monthly median daytime concentrations of $S_{O R G}$ in Hyytiälä, Finland, determined five different ways - three of which rely on GLOMAP data (blue, red and black solid lines) and two on measurement data from the PTR-MS (green dashed line), and one from the MT parameterization by Lappalainen et al. (2009) (brown dashed line). For details, see Sect. 2.2.3. Also, the monthly median sulfuric acid concentrations from proxy calculations and from GLOMAP (dashed yellow and orange lines, respectively) as well as their combined data set (solid gray line) are presented (see Sect. 2.2.2 for details).

concentrations, the behavior between measured and modeled monoterpene concentrations was similar to those for $\mathrm{SORG}_{\mathrm{MT}}$, suggesting that the variations in $\mathrm{SORG}_{\mathrm{MT}}$ are dominated by the monoterpene concentrations instead of the oxidant concentrations or the details of oxidation calculation (Eqs. 8-9). It should be also noted that only biogenic emissions are taken into account in GLOMAP as well as in the temperature-dependent parameterization. In Hyytiälä there are also some monoterpene emissions of anthropogenic origin, for instance because of a sawmill nearby (Liao et al., 2011).

The concentrations of SORG $\mathrm{MT}_{\mathrm{MT}}$ obtained directly from GLOMAP and determined using the monoterpene data from GLOMAP were in close agreement with each other (see Fig. 2). The small differences can be explained by the differences in the $\mathrm{O}_{3}, \mathrm{OH}$ concentrations and the condensation sink (CS) used in the calculations. The variations are reasonable, since the GLOMAP is not expected to capture the local changes in oxidant or aerosol concentrations that are observed with online measurements. There was a high peak in the $\mathrm{SORG}_{\mathrm{MT}}$ concentrations obtained directly from the GLOMAP in November (see Fig. 2). This peak was removed from the data analysis.

\subsubsection{Parameterization with differently calculated concentrations of SORG ${ }_{M T}$}

The weighing factors $\left(k_{\mathrm{MT}}\right)$ for distributing the $\mathrm{SORG}_{\mathrm{MT}}$ obtained from the mass flux fits using the five different data sets for the $\mathrm{SORG}_{\mathrm{MT}}$ for Hyytiälä (see Fig. 2 and Sect. 2.2.3) are presented in Table 3. While the mass flux fit showed some sensitivity to the input organic mass flux $\left(I_{\text {SORG, MT }}\right)$, relatively similar results and behavior were obtained using the different $\mathrm{SORG}_{\mathrm{MT}}$ data sets: the smallest particles were not
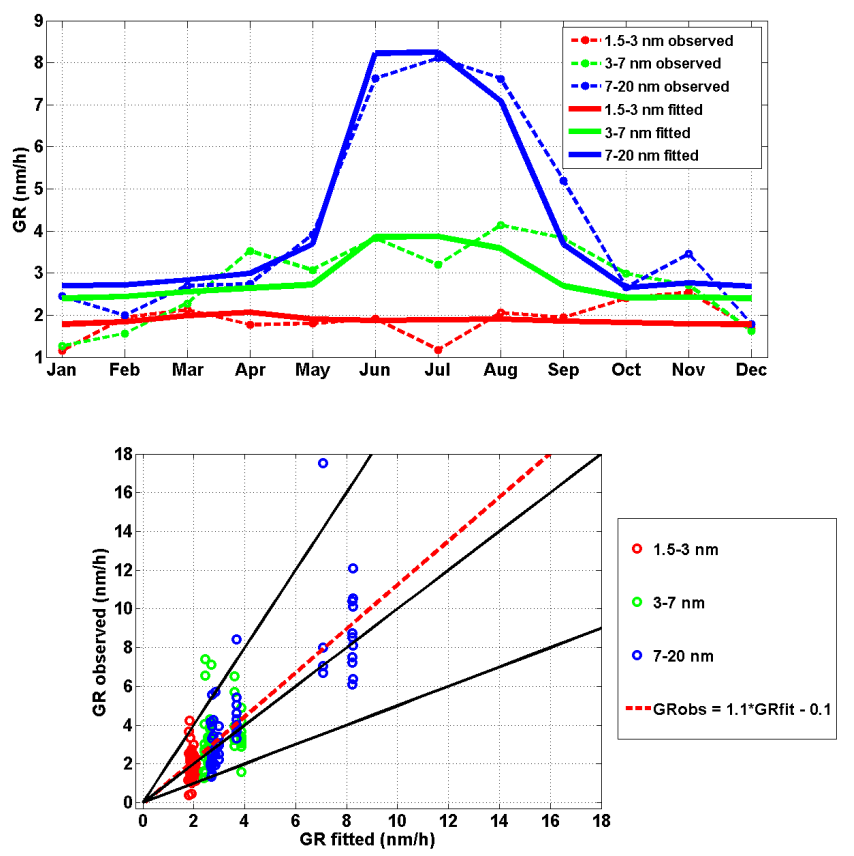

Fig. 3. Observed monthly median growth rates for three size ranges during 2003-2009 in Hyytiälä (symbols and dashed lines) and the growth rates from the mass flux fit (solid lines) using concentrations of SORG $_{\text {MT }}$ calculated using MT concentrations from GLOMAP (upper panel). See Table 3 for the fitting parameters. The correspondence between growth rates from the mass flux fit and from the ambient observations (monthly median growth rates for each year) is presented in the lower panel with a linear curve fitted to all the data points. Also, 1:1,2:1 and 1:2 lines (black lines) are shown.

growing by SORG $\mathrm{MT}_{\mathrm{MT}}$ but by sulfuric acid and the "background" condensing species due to the lack of seasonal variation in the observed GRs $\left(k_{\mathrm{MT}, 1.5-3}\right.$ was 0 for all the data sets) (see Fig. 3 for the observed seasonal behavior of GRs). The $k_{\mathrm{MT}}$ values for 3-7 and 7-20 nm particles ranged from 0.2 to 0.4 and from 0.6 to 1 , respectively. The largest particles were thus affected most by the SORG $\mathrm{GT}_{\mathrm{MT}}$ condensation. The vapor concentration, $C_{\mathrm{SORG}}$, bg, calculated based on the

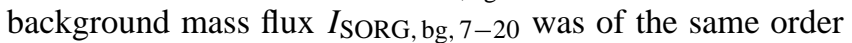
of magnitude $\left(10^{7} \mathrm{~cm}^{-3}\right)$ using different data sets (see Table 3). Weighing factors $\left(k_{\mathrm{bg}}\right)$ for distributing the $\mathrm{SORG}_{\mathrm{bg}}$ are also presented in Table 3.

The monthly growth rates obtained from the mass flux fit for the three size ranges $(1.5-3 \mathrm{~nm}, 3-7 \mathrm{~nm}$ and $7-$ $20 \mathrm{~nm}$ ) using the concentrations of $\mathrm{SORG}_{\mathrm{MT}}$ calculated using monoterpene concentrations from GLOMAP are presented in Fig. 3, upper panel (see Table 3 for the fitting parameters). The ambient growth rates observed during 20032009 in Hyytiälä are shown for comparison. The fit produced the seasonal pattern of particle growth rates well; the highest growth rates were observed during summer months in particle sizes $3-7 \mathrm{~nm}$ and $7-20 \mathrm{~nm}$, whereas the growth of the smallest particles $(1.5-3 \mathrm{~nm})$ was independent of the season. 
Table 3. Average concentrations of $\operatorname{SORG}_{\mathrm{MT}}\left(C_{\mathrm{SORG}} \mathrm{MT}, \mathrm{cm}^{-3}\right)$ and sulfuric acid $\left(C_{\mathrm{SA}}, \mathrm{cm}^{-3}\right)$ as well as the background concentration $\left(C_{\mathrm{SORG}}, \mathrm{bg}, \mathrm{cm}^{-3}\right)$ and weighing factors $\left(k_{\mathrm{MT}}\right.$ and $\left.k_{\mathrm{bg}}\right)$ from the mass flux fit in Hyytiälä. Differently defined concentrations of $\mathrm{SORG}_{\mathrm{MT}}$ ( $I_{\text {SORG, MT }}$ ) were used to test the functioning of the fit and its sensitivity to input data. Pearson's correlation coefficients $(R)$ with $p$ values (in parentheses) and parameters $a$ and $b\left(\mathrm{~nm} \mathrm{~h}^{-1}\right)$, obtained from a linear fit between the observed growth rates $\left(\mathrm{GR}_{\mathrm{obs}}\right.$ in $\left.\mathrm{nm} \mathrm{h}^{-1}\right)(2003-2009$, monthly medians for each year) and the growth rates obtained from the mass flux fit $\left(\mathrm{GR}_{\mathrm{fit}}\right.$ in $\left.\mathrm{nm} \mathrm{h}^{-1}\right)$ are presented.

\begin{tabular}{|c|c|c|c|c|c|}
\hline & $\begin{array}{c}1 \% \mathrm{MT} \\
\text { (GLOMAP) }\end{array}$ & $\begin{array}{r}\mathrm{SORG}_{\mathrm{MT}} \\
\text { (directly from } \\
\text { GLOMAP) }\end{array}$ & $\begin{array}{r}\text { SORG }_{\mathrm{MT}} \\
\text { (calculated, } \\
\text { GLOMAP) }\end{array}$ & $\begin{array}{r}\text { SORG }_{\mathrm{MT}} \\
\text { (calculated, } \\
\text { PTR-MS) }\end{array}$ & $\begin{array}{r}\text { SORG }_{\mathrm{MT}} \\
\text { (calculated } \\
\text { MT-parame- } \\
\text { terization) }\end{array}$ \\
\hline$C_{\mathrm{SA}}$ & $0.1 \times 10^{7}$ & $0.1 \times 10^{7}$ & $0.1 \times 10^{7}$ & $0.1 \times 10^{7}$ & $0.1 \times 10^{7}$ \\
\hline$C_{\text {SORG, MT }}$ & $2.3 \times 10^{7}$ & $1.9 \times 10^{7}$ & $2.5 \times 10^{7}$ & $3.7 \times 10^{7}$ & $5.6 \times 10^{7}$ \\
\hline$k_{\mathrm{MT}, 1.5-3}$ & 0 & 0 & 0 & 0 & 0 \\
\hline$k_{\mathrm{MT}, 3-7}$ & 0.2 & 0.3 & 0.2 & 0.4 & 0.2 \\
\hline$k_{\mathrm{MT}, 7-20}$ & 0.8 & 1.0 & 0.8 & 1.0 & 0.6 \\
\hline$C_{\text {SORG, bg }}$ & $3.8 \times 10^{7}$ & $3.8 \times 10^{7}$ & $3.6 \times 10^{7}$ & $2.1 \times 10^{7}$ & $2.5 \times 10^{7}$ \\
\hline$k_{\mathrm{bg}, 1.5-3}$ & 0.4 & 0.3 & 0.4 & 0.7 & 0.6 \\
\hline$k_{\mathrm{bg}, 3-7}$ & 0.7 & 0.7 & 0.8 & 0.9 & 0.8 \\
\hline$k_{\mathrm{bg}, 7-20}$ & 1.0 & 1.0 & 1.0 & 1.0 & 1.0 \\
\hline Correlation $R(p)$ & 0.78 & 0.80 & 0.80 & 0.65 & 0.67 \\
\hline $\mathrm{GR}_{\text {obs }}$ vs. $\mathrm{GR}_{\text {fit }}$ & $\left(<10^{-5}\right)$ & $\left(<10^{-5}\right)$ & $\left(<10^{-5}\right)$ & $\left(<10^{-5}\right)$ & $\left(<10^{-5}\right)$ \\
\hline Linear fit & $a=1.1$ & $a=1.4$ & $a=1.1$ & $a=1.0$ & $a=1.0$ \\
\hline $\begin{array}{l}\mathrm{GR}_{\mathrm{obs}}=a \\
\times \mathrm{GR}_{\mathrm{fit}}+b\end{array}$ & $b=-0.1$ & $b=-0.7$ & $b=-0.1$ & $b=0.2$ & $b=0.1$ \\
\hline
\end{tabular}

A line was fitted to the $\left(\mathrm{GR}_{\mathrm{fit}}, \mathrm{GR}_{\mathrm{obs}}\right)$-data to determine how close the data points were to a $1: 1$ line (described by the slope of the fitted line) and whether there was a systematic bias in the fitted growth rates (the intercept of the fitted line). The values of the slope and the intercept for each of the fitted cases are given in Table 3, along with the Pearson correlation coefficients and their $p$ values for the fitted vs. observed growth rates of all the sizes combined. We chose the simple Pearson correlation for the statistical analysis since no autocorrelation between the observed GRs was found. The correspondence between the $\mathrm{GR}_{\mathrm{obs}}$ and $\mathrm{GR}_{\mathrm{fit}}$ was generally very good: the slopes of the fitted lines varied between 1.0 and 1.4, and the systematic biases were less than $1 \mathrm{~nm} \mathrm{~h}^{-1}$ (for 4 cases out of 5 less than $0.3 \mathrm{~nm} \mathrm{~h}^{-1}$ ). These variations are similar to or less than the typical uncertainty in the observed GR values due to the experimental uncertainties and data analysis method (see Yli-Juuti et al., 2011; Leppä et al., 2013).

The correspondence between the $\mathrm{GR}_{\mathrm{obs}}$ and $\mathrm{GR}_{\mathrm{fit}}$ using SORG MT $_{\text {(calculated using monoterpene concentrations }}$ from GLOMAP) is shown in Fig. 3 (lower panel) for all the available data (monthly median $\mathrm{GR}_{\mathrm{obs}}$ separately from years 2003-2009). The reason for the accumulation of the data points is that $\mathrm{GR}_{\text {fit }}$ is getting only one value per month ( $k_{\mathrm{MT}}, k_{\mathrm{bg}}$ and $C_{\mathrm{SORG}}$, bg determined using monthly medians of SORG $\mathrm{G}_{\mathrm{MT}}$ over a single year) while the monthly median $\mathrm{GR}_{\text {obs }}$ changes through years. There was a clear positive correlation between the fitted and observed GRs, account- ing for all the GR data from different size ranges $(R=0.80$, $p<10^{-5}$ ). In general the correlation between the fitted and observed GRs at certain particle size was better the more variability the GRs showed, i.e., the best correlation was observed in the $7-20 \mathrm{~nm}$ size range $\left(R=0.81, p<10^{-5}\right)$. For the smallest size class, correlation was the poorest $(R=$ $-0.15, p=3 \times 10^{-1}$ ) even though the fitted GRs clearly corresponded to those observed (see Fig. 3). The correspondence between the $\mathrm{GR}_{\mathrm{obs}}$ and $\mathrm{GR}_{\text {fit }}$ was very good: data points were aligned on the $1: 1$ line. These results show that the fit is able to capture the observed growth rates and their seasonal pattern in Hyytiälä. The good agreement shows that the seasonal variability is clearly more important in determining the growth rates as compared with the interannual variability (represented by the y-directed scatter in the data in Fig. 3).

To test the robustness of Eq. (1) as a parameterization function, the fits were also performed setting the $I_{\text {SORG, MT }}$ and the $I_{S O R G}$ bg to zero one at a time. Neither the SORG $\mathrm{MT}_{\mathrm{M}}$ nor the SORG $\mathrm{bg}_{\mathrm{b}}$ could produce the observed GRs alone. Figure 4 illustrates the case where the background mass flux is assumed zero, i.e., only SORG $_{\mathrm{MT}}$ and sulfuric acid are growing the particles. Even though the seasonal variation in the particle growth can be estimated fairly well without the background, the GRs are systematically underestimated especially during colder seasons when the concentrations of SORG $\mathrm{MT}_{\mathrm{MT}}$ are lower. If only the constant background 
Table 4. Average concentrations of $\operatorname{SORG}_{\mathrm{MT}}\left(C_{\mathrm{SORG}} \mathrm{MT}, \mathrm{cm}^{-3}\right)$ and sulfuric acid $\left(C_{\mathrm{SA}}, \mathrm{cm}^{-3}\right)$ as well as the background concentration $\left(C_{\mathrm{SORG}, \mathrm{bg}}, \mathrm{cm}^{-3}\right)$ and weighing factors $\left(k_{\mathrm{MT}}\right.$ and $\left.k_{\mathrm{bg}}\right)$ from the mass flux fit using EUCAARI data (including and excluding Hyytiälä). Monthly median growth rates were averaged over all the six European stations (Hyytiälä included, 2003-2009). Pearson's correlation coefficients $(R)$ with $p$ values (in parentheses) and parameters $a$ and $b\left(\mathrm{~nm} \mathrm{~h}^{-1}\right)$, obtained from a linear fit between the observed growth rates $\left(\mathrm{GR}_{\mathrm{obs}}\right.$ in $\mathrm{nm} \mathrm{h}^{-1}$ ) (monthly medians for each station) and the growth rates obtained from the mass flux fit $\left(\mathrm{GR}_{\mathrm{fit}}\right.$ in $\left.\mathrm{nm} \mathrm{h}^{-1}\right)$, are presented.

\begin{tabular}{lrr}
\hline & Six sites & Five sites \\
\hline$C_{\mathrm{SA}}$ & $0.5 \times 10^{7}$ & $0.7 \times 10^{7}$ \\
\hline$C_{\mathrm{SORG}}, \mathrm{MT}$ & $0.9 \times 10^{7}$ & $0.8 \times 10^{7}$ \\
$k_{\mathrm{MT}, 1.5-3}$ & 0 & 0 \\
$k_{\mathrm{MT}, 3-7}$ & 0.7 & 0.7 \\
$k_{\mathrm{MT}, 7-20}$ & 1.0 & 1.0 \\
\hline$C_{\mathrm{SORG}}$ bg & $5.8 \times 10^{7}$ & $6.4 \times 10^{7}$ \\
$k_{\mathrm{bg}, 1.5-3}$ & 0.3 & 0.3 \\
$k_{\mathrm{bg}, 3-7}$ & 0.7 & 0.8 \\
$k_{\mathrm{bg}, 7-20}$ & 1.0 & 1.0 \\
\hline Correlation $R(p)$ & 0.45 & 0.45 \\
$\mathrm{GR}_{\text {obs }}$ vs. $\mathrm{GR}_{\mathrm{fit}}$ & $\left(<10^{-5}\right)$ & $\left(<10^{-5}\right)$ \\
\hline Linear fit & $a=0.8$ & $a=0.7$ \\
$\mathrm{GR}_{\text {obs }}=a \times \mathrm{GR}_{\mathrm{fit}}+b$ & $b=0.9$ & $b=0.8$ \\
\hline
\end{tabular}

mass flux is accounted for, the seasonal variation of the GRs in the size ranges of $3-7 \mathrm{~nm}$ and $7-20 \mathrm{~nm}$ cannot be reproduced (Fig. 5).

\subsection{Growth parameterization using EUCAARI data}

The proposed parameterization (Eq. 1) performed well in Hyytiälä. To obtain results relevant also on a broader scale, data sets from other measurement stations around Europe were included in the analysis. Determination of statistically significant $k$ values for individual stations (apart from Hyytiälä) was not possible due to the small amount of data from each station (see Sect. 2.2.1). Therefore, monthly median growth rates averaged over all the stations were used in the mass flux fitting. For the concentrations of the SORG $\mathrm{MT}_{\mathrm{MT}}$ and sulfuric acid, we used data from GLOMAP (average over all the stations), thus ensuring consistent treatment of all the stations. The results obtained from the analysis for Hyytiälä (Sect. 3.1.2) give confidence for using the concentrations of SORG $\mathrm{MT}_{\mathrm{MT}}$ directly from GLOMAP in the fitting, as the correspondence between fitted and ambient growth rates was reasonable.

Figure 6 shows how well the fit produced the observed growth rates using data from all six stations. The correspondence between the fitted and observed growth rates was rela-
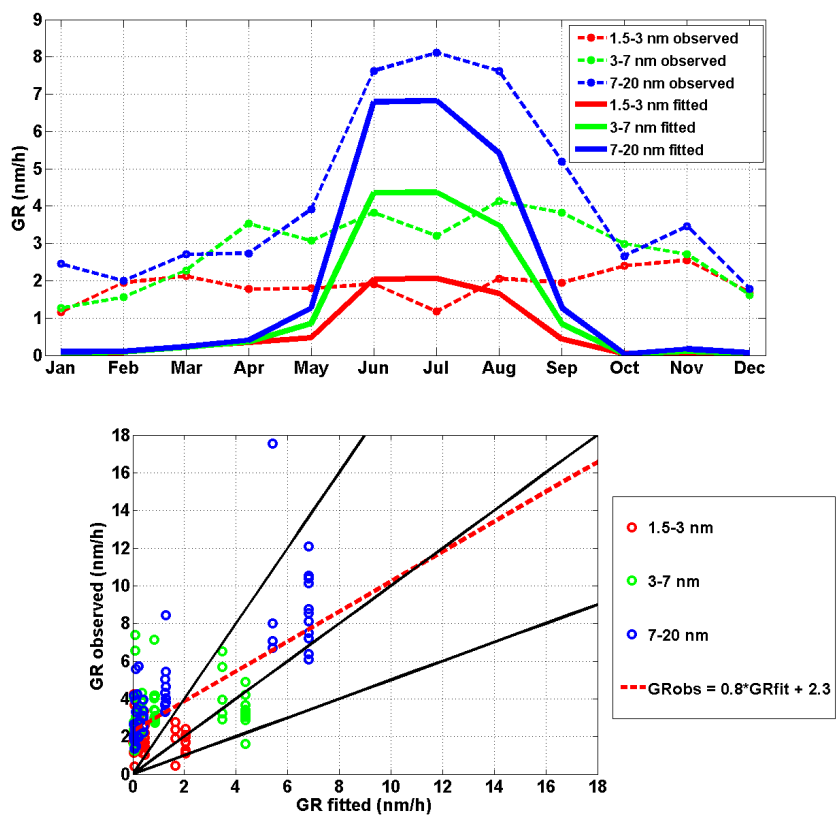

Fig. 4. Observed monthly median growth rates for three size classes during 2003-2009 in Hyytiälä (symbols and dashed lines) as well as the growth rates obtained from the mass flux fit (solid lines) when background mass flux is assumed to be zero (upper figure). The weighing factors for distributing the $\mathrm{SORG}_{\mathrm{MT}}$ (calculated using MT concentrations from GLOMAP) corresponding to the best fit were $k_{\mathrm{MT}, 1.5-3}=0.2, k_{\mathrm{MT}, 3-7}=0.5$ and $k_{\mathrm{MT}, 7-20}=1.0$. The correspondence between the growth rates from the mass flux fit and from the ambient observations is presented in the lower figure with a linear curve fitted to all the data points. Also $1: 1,2: 1$ and $1: 2$ lines (black lines) are shown. The fit can produce similar seasonal behavior as observed in the ambient conditions. However, the GRs are clearly underestimated during cold months when the emissions of MT are low.

tively good, taking into account that we fitted Eq. (1) to averaged data from six sites with different characteristics. The correlation coefficient obtained was $R=0.45\left(p<10^{-5}\right)$ with a slope and intercept of 0.8 and $0.9 \mathrm{~nm} \mathrm{~h}^{-1}$ for the linear fit to GR data points. The weighing factors for the $S_{O R G}$ and the $S O R G_{\mathrm{bg}}$ obtained from the mass flux fit are presented in Table 4. Results using all the available data (six stations, Hyytiälä included) and data excluding Hyytiälä (five stations) are shown. The weighing factors $\left(k_{\mathrm{MT}}\right)$ were the same in both cases, with 0 for $1.5-3 \mathrm{~nm}, 0.7$ for $3-7 \mathrm{~nm}$ and 1 for $7-20 \mathrm{~nm}$. Background concentrations $\left(C_{\mathrm{SORG}, \mathrm{bg}}\right)$ were also similar, around $6 \times 10^{7} \mathrm{~cm}^{-3}$ like the $k_{\mathrm{bg}}$ values for both cases.

Overall the growth of the nanoparticles $\left(3-10 \mathrm{~nm} \mathrm{~h}^{-1}\right)$ could be predicted within, on average, $15 \%$ using Eq. (1). The performance quality of the parameterization deteriorated with lower growth rate values: observed GR of $2 \mathrm{~nm} \mathrm{~h}^{-1}$ was overestimated by as much as $50 \%$, on average. Of the thermodynamic parameters used in the mass flux equations (see 

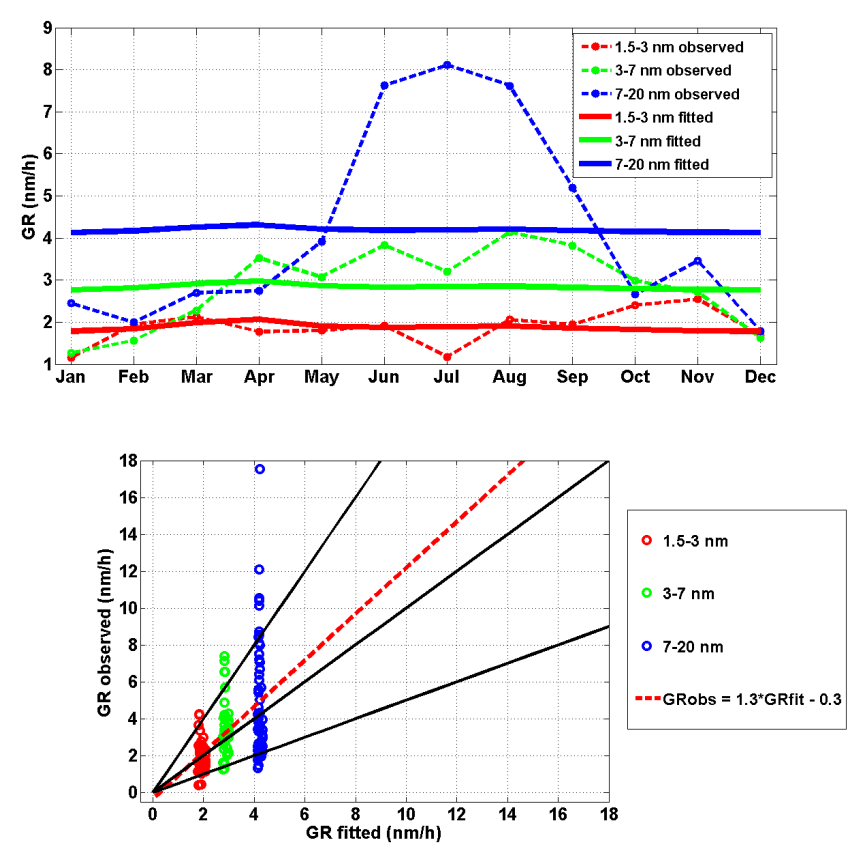

Fig. 5. Observed monthly median growth rates for three size classes during 2003-2009 in Hyytiälä (symbols and dashed lines) as well as the growth rates obtained from the mass flux fit (solid lines) when organic mass flux ( $I_{\mathrm{SORG}}, \mathrm{MT}$ ) is assumed to be zero (upper panel). The background concentration obtained from the fit was $C_{\text {SORG, bg }}=5.7 \times 10^{7} \mathrm{~cm}^{-3}$ with weighing factors for $\mathrm{SORG}_{\mathrm{bg}}$ 0.2 for $1.5-3 \mathrm{~nm}, 0.6$ for $3-7 \mathrm{~nm}$ and 1 for $7-20 \mathrm{~nm}$. The correspondence between the growth rates from the mass flux fit and from the ambient observations is presented in the lower panel with a linear curve fitted to all the data points. Also, $1: 1,2: 1$ and $1: 2$ lines (black lines) are shown. The seasonal behavior in 3-20 nm particles cannot be captured this way.

Table 1), the densities of the aerosol particles $\rho_{\mathrm{p}}$ and the organics $\rho_{\mathrm{ORG}}$ had the greatest influence on the fit parameters $k_{\mathrm{MT}, 3-7}$ and $C_{\mathrm{SORG}}$, bg both being around $20 \%$ lower/higher with lower/higher densities $\left(1.3 / 1.7 \mathrm{~g} \mathrm{~cm}^{-3}\right)$ compared to the base case (other $k_{\mathrm{MT}}$ values and $k_{\mathrm{bg}}$ values were not affected). Lowering the accommodation coefficients $\alpha_{\mathrm{m}, \mathrm{SA}}$ and $\alpha_{\mathrm{m}, \text { ORG }}$ to 0.9 increased both the $k_{\mathrm{MT}, 3-7}$ and $C_{\mathrm{SORG}}$, bg values around $15 \%$ (other $k_{\mathrm{MT}}$ values and $k_{\mathrm{bg}}$ values were not affected). A positive bias of $2 \mathrm{~nm} \mathrm{~h}^{-1}$ in the observed GRs increased the $C_{\mathrm{SORG}}$, bg, with $50 \%$ increasing also $k_{\mathrm{bg}, 1.5-3}$ by $25 \%$ (other $k_{\text {bg }}$ were not affected), whereas a negative bias of $2 \mathrm{~nm} \mathrm{~h}^{-1}$ gave approximately $50 \%$ lower $C_{\text {SORG, bg }}$, with $60 \%$ and $15 \%$ lower $k_{\mathrm{bg}, 1.5-3}$ and $k_{\mathrm{bg}, 3-7}$ values, respectively. The $k_{\mathrm{MT}}$ values for distributing the $\mathrm{SORG}_{\mathrm{MT}}$ were not affected. The highest uncertainties are associated with the determination of the growth of sub-3nm particles from observations (e.g., Yli-Juuti et al., 2011; Leppä et al., 2013) partly explaining the poorer correspondence between fitted and observed growth in the $1.5-3 \mathrm{~nm}$ size range (see Fig. 6). Also, the statistical uncertainty of GR values is higher during winter months when the number of particle formation
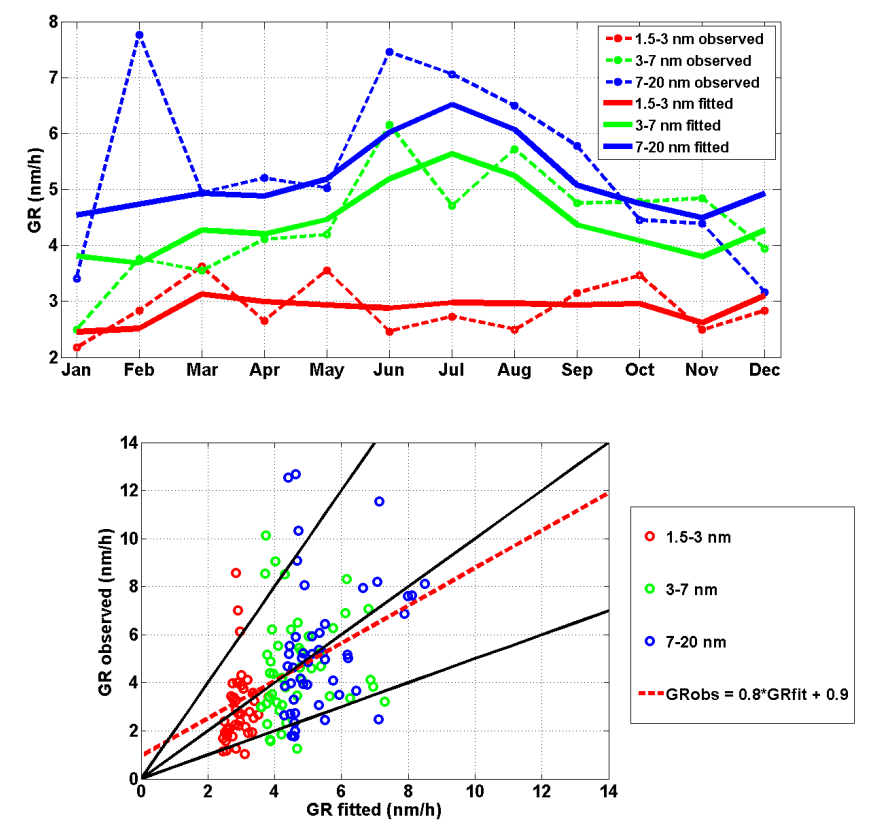

Fig. 6. Ambient monthly median growth rates averaged over all the studied European sites (symbols and dashed lines) for three size ranges and the growth rates from the mass flux fit (solid lines) using $\mathrm{SORG}_{\mathrm{MT}}$ obtained directly from GLOMAP (upper panel). See Table 4 for the fitting parameters. The GR data for February was not included in the fitting since it was strongly affected by one highGR event day $\left(\mathrm{GR}_{7-20}>20 \mathrm{~nm} \mathrm{~h}^{-1}\right)$ in Finokalia, making this data point unreliable. The correspondence between the growth rates from the mass flux fit and from the ambient observations (monthly median growth rates for each station) is presented in the lower panel with a linear curve fitted to all the data points. Also, 1:1,2:1 and $1: 2$ lines (black lines) are shown.

events is lower than during other seasons (see Yli-Juuti et al., 2011). The uncertainty in the used SORG $\mathrm{ST}_{\mathrm{MT}}$ concentrations was also highest during winter months (see Fig. 2).

The performance of the EUCAARI parameterization at individual stations was also investigated (Fig. A1, Appendix A). Particle growth rates were somewhat overestimated for Hyytiälä and Vavihill, whereas for K-Puzsta, Melpitz and Hohenpeissenberg the correspondence was generally good. The growth of the smallest particles $(1.5-3 \mathrm{~nm})$ was reproduced well in Finokalia, but for the larger particles the fit reproduced somewhat too low values. It is notable that while these comparisons give some hint on the performance of the parameterization in different environments, they should be treated with caution due to the statistically too low number of data points from each station.

The fitting parameters (Table 4) were based on monthly GR data. To test the performance of the parameterization on a daily basis, daily GRs were calculated for the six sites and compared with the observed GRs (Fig. 7). The agreement on a daily basis was naturally poorer (the slope of the fitted line being 0.7 and the systematic bias $1.3 \mathrm{~nm} \mathrm{~h}^{-1}$, correlation 
coefficient of 0.38) as compared with the monthly data (see Fig. 6), but still deemed to be reasonable.

\section{Discussion: on the implications and applicability of the parameterization}

The parameterization based on Eq. 1 and the semi-empirical fitting parameters is a simplistic representation of the sub$20 \mathrm{~nm}$ particle growth and distribution of $\mathrm{SORG}_{\mathrm{MT}}$ and $\mathrm{SORG}_{\mathrm{bg}}$ onto the aerosol size distribution, but it captures the observed behavior of nanoparticle growth relatively well. Particle growth rates obtained from the parameterization increase with particle size, as observed in various environments around the world (e.g., Hirsikko et al., 2005; Iida et al., 2008; Manninen et al., 2010; Yli-Juuti et al., 2011; Kuang et al., 2012; Kulmala et al., 2013), and the magnitude and seasonal pattern of the growth rates is similar to observations (Kulmala et al., 2004; Dal Maso et al., 2005; Hirsikko et al., 2005; Manninen et al., 2010). The parameterization is also fairly insensitive to the method of calculating the sulfuric acid and monoterpene concentrations, as long as their temporal patterns and order of magnitude are reasonable.

Two alternative sets of fitting parameters were presented: one that was based on $7 \mathrm{yr}$ of size distribution data from Hyytiälä, Finland, and one based on about one year of data from 6 European sites with different characteristics. The strength of the former is the longer temporal span (and thus better statistics on the GR values) and better selection of input data for the fitting, while the latter covers spatially more diverse environments with different gas phase compositions and meteorological conditions. The results from the two fits gave qualitatively similar results, with the $k_{\mathrm{MT}}$ factors for distributing the $\mathrm{SORM}_{\mathrm{MT}}$ being 0 for the $1.5-3 \mathrm{~nm}$ particles and approaching 1 as the particles grew towards $20 \mathrm{~nm}$. For the $3-20 \mathrm{~nm}$ particles, the fits to Hyytiälä data gave slightly lower $k_{\mathrm{MT}}$ factors $\left(k_{\mathrm{MT}, 3-7}=0.2-0.4\right.$ and $k_{\mathrm{MT}, 7-20}=0.6-$ 1.0, depending on the SORG $\mathrm{G}_{\mathrm{MT}}$ data) than the corresponding values based on the EUCAARI data $\left(k_{\mathrm{MT}, 3-7}=0.7\right.$ and $k_{\mathrm{MT}, 7-20}=1.0$ ). The concentration of the "background" condensable species were of the order of $10^{7} \mathrm{~cm}^{-3}$ for both data sets, the fits to the EUCAARI data giving slightly higher values than the fits to the Hyytiälä data. It should be borne in mind that these concentrations describe the SORG during specific conditions of well characterized daytime new particle formation.

The CCN production is very sensitive to the competition between growth and coagulation losses (Kerminen and Kulmala, 2002; Pierce and Adams, 2007; Kuang et al., 2009; Riipinen et al., 2011; Vehkamäki and Riipinen, 2012). The sizedependence of particle growth thus needs to be accounted for to improve the predictions of the contribution of new particle formation to $\mathrm{CCN}$ concentrations in atmospheric models (Kuang et al., 2012). The $k_{\mathrm{MT}}\left(d_{\mathrm{p}}\right)$ values presented in this paper offer a relatively straightforward way of doing this in any model that calculates the condensation of $\mathrm{SORG}_{\mathrm{MT}}$ similarly to that of sulfuric acid (i.e., as non-volatile and distributed to the aerosol surface area) as they can be used to simply multiply the contribution of nanoparticles with size $d_{\mathrm{p}}$ to the condensation sink when distributing the SORG to the aerosol size distribution. This method is also applicable when distributing the "background" organics.

The choice of a set of appropriate $k_{\mathrm{MT}}$ values for distributing the SORG $\mathrm{MT}_{\mathrm{MT}}$ (Tables 3 and 4) for a specific model depends on the application (e.g., the way the monoterpene emissions are treated). The average values based on the Hyytiälä data were $0,0.3$ and 0.8 for $k_{\mathrm{MT}, 1.5-3}, k_{\mathrm{MT}, 3-7}$, and $k_{\mathrm{MT}, 7-20}$, with $C_{\mathrm{SORG}}$ bg $=3 \times 10^{7} \mathrm{~cm}^{-3}$. The corresponding values for the EUCAARI data were $0,0.7$ and 1 , with $C_{\mathrm{SORG}}$, bg $=6 \times 10^{7} \mathrm{~cm}^{-3}$. For studies focusing on boreal forest conditions the former should be used, whereas for cases studying larger and more variable regions the latter is probably better. It should be noted that the data used in this analysis is limited - only temperate continental boundary layer sites were studied - and therefore we cannot conclude how the nanoparticle growth should be parameterized in global models for other kinds of environments, e.g., over the arctic areas, deserts or tropics.

In addition to the size-dependent growth of nanoparticles by $\mathrm{SORG}_{\mathrm{MT}}$, condensation of an additional "background" vapor with no seasonal dependence was needed to reproduce the observed growth. This was largely due to the fact that the growth of the smallest $1.5-3 \mathrm{~nm}$ particles did not show seasonal dependence (i.e., grew when there were practically no biogenic monoterpenes around), and on the other hand grew faster than just sulfuric acid condensation could explain. Particle growth by sulfuric acid has uncertainties that arise from uncertainties in measurements and in the calculation of $I_{\mathrm{SA}}$. These uncertainties can affect our GR parameterization - particularly for the smallest particles. To explain the GRs with only sulfuric acid and SORG $\mathrm{MT}_{\mathrm{MT}}$, the sulfuric acid concentrations would have to be approximately 10-20 times higher than used in our analysis. Besides the experimental uncertainty in the detection of gas-phase sulfuric acid (on which the sulfuric acid concentrations used in the calculations rely), this uncertainty could also be caused by, e.g., significant clustering of the sulfuric acid or other effects that are not accounted for in the $I_{\mathrm{SA}}$ calculation. The sulfuric acid closure study by Boy et al. (2005) suggests, however, that the measured sulfuric acid concentrations can be reproduced with a chemical kinetics model, indicating that at least the order of magnitude of the sulfuric acid concentration (including the potential clusters) should be reasonable. In the following we discuss other possible origins of the "background" and apply model simulations using a global model to support our discussion.

One possible candidate for the "background" vapor is a combination of anthropogenic and biogenic organics, for instance SOA formed from biogenic organics in the presence of anthropogenic pollution (Hoyle et al., 2011; Spracklen et 


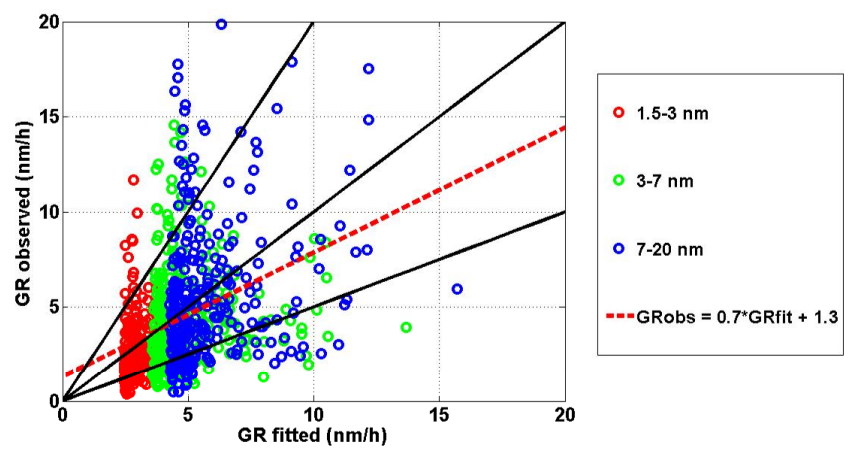

Fig. 7. The correspondence between the growth rates from the mass flux fit and from the ambient observations (daily growth rates for each station) with a linear curve fitted to all the data points. Also, $1: 1,2: 1$ and $1: 2$ lines (black lines) are shown. The correlation coefficient between the $\mathrm{GR}_{\mathrm{fit}}$ and the $\mathrm{GR}_{\mathrm{obs}}$ was 0.38 with a $p$ value of $<10^{-5}$.

al., 2011). Another possible explanation for the relatively fast season-independent growth of the smallest nanoparticles could be the contribution of, e.g., amines or ammonia, which could both contribute to the growth of sub- $3 \mathrm{~nm}$ particles as well as influence the calculated contribution of sulfuric acid (Kirkby et al., 2011; Kulmala et al., 2013). It should, however, be noted that an accurate determination of the GR values below $3 \mathrm{~nm}$ is very challenging and thus subject to relatively large errors, particularly for the smallest particle growth rates (see, e.g., Yli-Juuti et al., 2011; Leppä et al., 2013). This naturally adds uncertainty to the parameterization as well. The concentration of the "background" vapor thus probably cannot be constrained further than within an order of magnitude based on our data. It is notable, however, that the concentration values obtained from the fits are relatively large, comparable to those of sulfuric acid and $\mathrm{SORG}_{\mathrm{MT}}$ (Tables 3-4). The contribution of this material also varies with particle size, as indicated by the weighing factors $\left(k_{\mathrm{bg}}\right)$ (Tables 3-4).

While the size-dependent weighing factors for the distribution of $\mathrm{SORG}_{\mathrm{MT}}$ onto nanoparticles are relatively straightforward to implement to models, we realize that the inclusion of the background condensable species might be problematic as it requires an emission of an unidentified precursor. This precursor could be similar to the extra SOA treated by Spracklen et al. (2011) or, e.g., a fraction of some other condensable material treated in the model, as discussed above. We used the GEOS-Chem-TOMAS model (as described in Pierce et al., 2013) to study the seasonal behavior of this extra SOA and to determine if it can be used to describe our "background". As suggested by Spracklen et al. (2011),

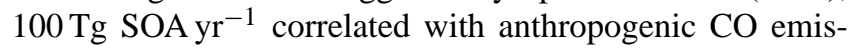
sions was added to the model beyond the standard biogenic SOA-precursor emissions. These extra SOA emissions contributed to annual mean condensable organic vapor concentrations of about $1 \times 10^{8} \mathrm{~cm}^{-3}$ in the model grid cell contain- ing Hyytiälä. These concentrations are a factor of 3 higher than was calculated for the "background" condensable organics for larger particles at Hyytiälä and about $50 \%$ higher than the "background" condensable organics at the other 5 sites. The high bias against Hyytiälä can be expected since the large, $4^{\circ} \times 5^{\circ}$ grid boxes in GEOS-Chem-TOMAS could include many anthropogenic sources in the Hyytiälä grid box that would not affect the measurements at this remote location. Furthermore, the seasonal cycle of these extra condensable organics ( \pm a factor of 2 ) is significantly weaker than the seasonal cycle in monoterpenes ( \pm a factor of 5-10) and is driven primarily by the seasonal variation in BL height (which causes a maximum concentration in the winter). The weak seasonal cycle is consistent with our analysis here where a constant "background" organic concentration was sufficient. Thus, we conclude that the extra, non-traditional biogenic sources of SOA (e.g., the $100 \mathrm{Tg} \mathrm{SOA} \mathrm{yr}^{-1}$ correlated with anthropogenic $\mathrm{CO}$ emissions, Spracklen et al., 2011) may be responsible for the "background" organic concentrations in our study.

If other aerosol modelers wish to use this "extra SOA" approach to create the "background" SOA, we recommend using the following $k_{\mathrm{bg}}$ values for the size dependence of condensation for the "background" organics for larger continental regions: $k_{\mathrm{bg}, 1.5-3}=0.3, k_{\mathrm{bg}, 3-7}=0.8$ and $k_{\mathrm{bg}, 7-20}=$ 1.0 (for the boreal forest $k_{\mathrm{bg}, 1.5-3}=0.4, k_{\mathrm{bg}, 3-7}=0.8$ and $\left.k_{\mathrm{bg}, 7-20}=1.0\right)$. On the other hand, if no "background" vapor is represented in the model (i.e., $C_{\mathrm{SORG}}$, bg $=0$ ), we recommend using the $k_{\mathrm{MT}}$ factors determined without $I_{\mathrm{SORG}}$ bg in Eq. (1), i.e., $k_{\mathrm{MT}, 1.5-3}=0.2, k_{\mathrm{MT}, 3-7}=0.5$ and $k_{\mathrm{MT}, 7-20}=$ 1.0 for the boreal forest and $k_{\mathrm{MT}, 1.5-3}=1.0, k_{\mathrm{MT}, 3-7}=1.0$ and $k_{\mathrm{MT}, 7-20}=1.0$ for larger continental regions. It should be noted, however, that neglecting the "background" contribution is likely to result in underprediction of the magnitude of the growth rates even though their seasonal dependence is captured (see Fig. 4).

Our parameterization is expected to give satisfactory results for nanoparticle growth on the scale at which many global models operate (Figs. 3 and 6), i.e., reproducing the observed seasonal patterns rather than capturing the daily variation of the growth. Additionally, uncertainties in the observed GRs and the modeled daily concentrations of sulfuric acid and SORG $\mathrm{MT}_{\mathrm{T}}$ cause scatter to the comparison of observed and parameterized GRs when investigating individual growth episodes (Fig. 7). There are still several improvements that can be expected as the mechanistic understanding of the SOA formation and nanoparticle growth processes increases. One of the caveats related to the commonlyused methods of determining ambient size-dependent growth rates is the coupling of particle size with time (see, e.g., Kuang et al., 2012). We do not expect this to be an issue over the timescales at which we are operating (as we do not consider diurnal variation in the vapor concentrations), and acknowledge that the temporal variation is probably a factor contributing the semi-empirical parameters $k_{\mathrm{MT}}$ and 
$k_{\mathrm{bg}}$. Another potential point of improvement is related to the mechanistic understanding of the role of amines and ammonia, which are important in the early steps (below $3 \mathrm{~nm}$ ) of nanoparticle formation and growth (see, e.g., Berndt et al., 2010; Kirkby et al., 2011; Riipinen et al., 2012; Yu et al., 2012; Kulmala et al., 2013), affecting also the predicted contribution of sulfuric acid on the GR values. As new knowledge on the early steps of the growth is obtained, the parameterization should be updated accordingly. It should be also noted that coagulational growth of nanoparticles was not accounted for in the parameterization. This is certainly a good assumption in remote environments with relatively low aerosol concentrations, but will add uncertainty to the fit parameters in more polluted environments (see, e.g., Kerminen and Kulmala, 2002; Stolzenburg et al., 2005; Leppä et al., 2011).

\section{Summary and conclusions}

We have introduced a semi-empirical parameterization of atmospheric nanoparticle growth as a function of ambient concentrations of sulfuric acid and first-order oxidation products of monoterpenes $\left(\mathrm{SORG}_{\mathrm{MT}}\right)$, the latter multiplied by a fitted weighing factor with values between 0 and 1 . Through its dependence on the monoterpene oxidation products, the formula couples nanoparticle growth to the distribution of $\mathrm{SORG}_{\mathrm{MT}}$ to the atmospheric aerosol size distribution. The weighing factors for the distributing $\mathrm{SORG}_{\mathrm{MT}}$ onto 1.5$3 \mathrm{~nm}, 3-7 \mathrm{~nm}$ and $7-20 \mathrm{~nm}$ particles were determined using seven years (2003-2009) of particle growth rate data from Hyytiälä, and a year (2008-2009) of corresponding data from five other sites around Europe (see Eq. 1 and Tables 3, 4 for the weighing factors). The results indicate that as the particles get larger, a greater fraction of the $\mathrm{SORG}_{\mathrm{MT}}$ can condense onto the particles and cause them to grow. This result is reasonable in light of the thermodynamics of evaporation, as Kelvin effect affects the mass flux onto the smallest particles, decreasing the maximum condensing fraction of the total available condensable material. This result is also in line with atmospheric observations.

Besides the condensation of sulfuric acid and $\mathrm{SORG}_{\mathrm{MT}}$, a third condensing vapor, referred to as "background", was needed to explain the observed nanoparticle growth rates. The concentration of this vapor was assumed to be constant throughout the year and its value was determined to be of the order of $10^{7} \mathrm{~cm}^{-3}$ through fits to ambient data (see Tables 3 and 4 for the detailed values). The background concentration was comparable to that of sulfuric acid and the monoterpene oxidation products, and thus contributes significantly to the growth of the atmospheric nanoparticles, especially at the smallest particle sizes. The exact identity of this "background" vapor (or vapor mixture) is not clear, although it is speculated to account for non-monoterpene organics or, e.g., the impacts of amines on the growth of the smallest particles.
As the amount of available data on atmospheric nanoparticle growth and gas phase composition increases, explaining this "background" contribution or its dependence on environmental parameters will be an interesting topic for a future study.

To study the performance of the parameterization function and its sensitivity to input data, different ways of estimating the $\mathrm{SORG}_{\mathrm{MT}}$ concentrations were used. The fit showed some sensitivity to the input data (see Table 3 and Sect. 3.1.2 for details), but the overall patterns and magnitude of the fitting parameters were consistent in the different investigated cases. Similarly, although some differences existed between the results from Hyytiälä alone and all other six European sites (see Tables 3-4), the results were consistent. The weighing factors for $\mathrm{SORG}_{\mathrm{MT}}$ condensation consistently increased with size, being 0 for $1.5-3 \mathrm{~nm}$ particles and approaching unity (i.e., kinetic limit) for $20 \mathrm{~nm}$ particles. The concentration of the "background" vapor was of the order of $10^{7} \mathrm{~cm}^{-3}$ for both cases while the condensation of the background was size-dependent. The parameterization function produced the observed monthly growth rates well, usually within factor of 2 and often within $30 \%$.

Since the CCN production from nucleation is very sensitive to the competition between coagulational scavenging and condensational growth, we expect the presented parameterization to improve the performance of atmospheric models in predicting the contribution of new particle formation to $\mathrm{CCN}$ concentrations. To verify its usefulness and performance in the future, however, the parameterization should be tested within a large-scale atmospheric model and evaluated against a growth rate data set independent of the data utilized to obtain it.

\section{Appendix A}

Diffusion coefficient for vapor molecules $\left(D_{\mathrm{v}}\right)$ in a background gas (air) can be determined by using a semi-empirical formula presented by Poling et al. (2001):

$D_{\mathrm{v}}=\frac{0.001 T^{1.75}}{p\left(\Sigma_{\text {air }}^{1 / 3}+\Sigma_{\mathrm{v}}^{1 / 3}\right)} \sqrt{\frac{1}{M_{\text {air }}}+\frac{1}{M_{\mathrm{v}}}}$,

where $D_{\mathrm{v}}$ is given in $\mathrm{cm}^{2} \mathrm{~s}^{-1}, T$ is temperature (in Kelvin units), $p$ is pressure (in atm units), $M_{\text {air }}$ is molar mass of air (in $\mathrm{g} / \mathrm{mol}$ ) and $M_{\mathrm{v}}$ is molar mass of the vapor (in $\mathrm{g} \mathrm{mol}^{-1}$ ), $\Sigma_{\text {air }}^{1 / 3}$ is diffusion volume of air, and $\Sigma_{\mathrm{v}}^{1 / 3}$ is diffusion volume of condensable vapor (can be obtained from tabulated diffusion volumes of atoms; see, e.g., Poling et al., 2001).

Diffusion coefficient for particles of a certain size $\left(d_{\mathrm{p}}\right)$ in a medium (air) can be determined from

$D_{\mathrm{p}}=\frac{k_{\mathrm{B}} T C_{\mathrm{c}}}{3 \pi \mu d_{\mathrm{p}}}$, 

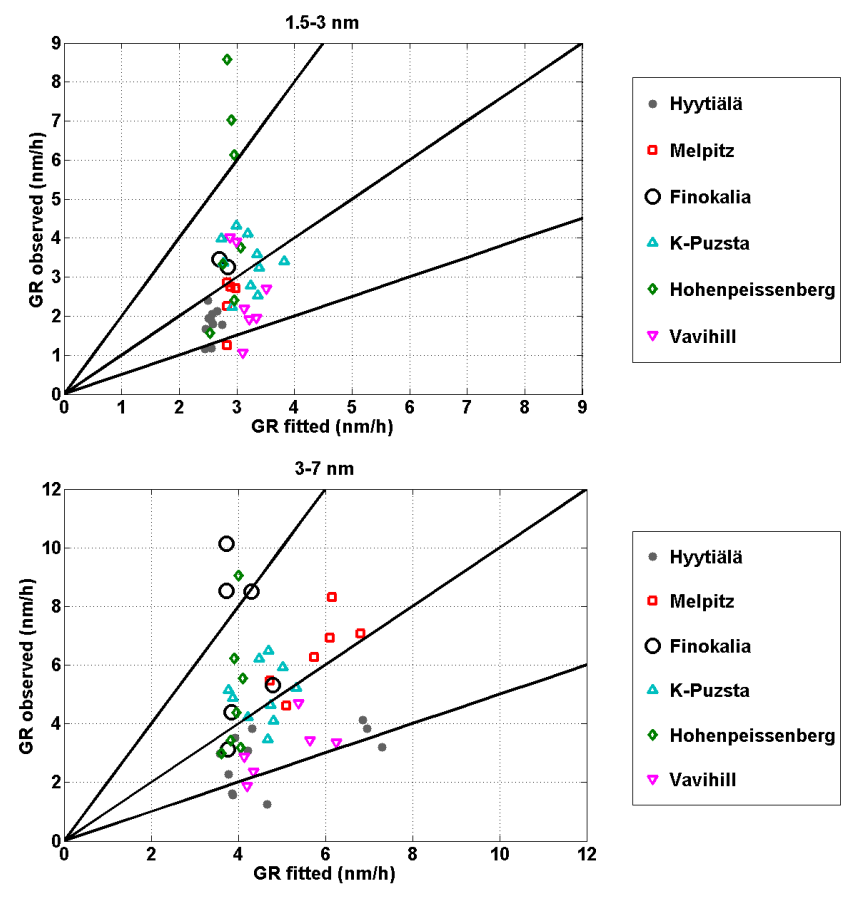

- Hyytiälä

口 Melpitz

O Finokalia

$\triangle$ K-Puzsta

* Hohenpeissenberg

$\nabla$ Vavihill

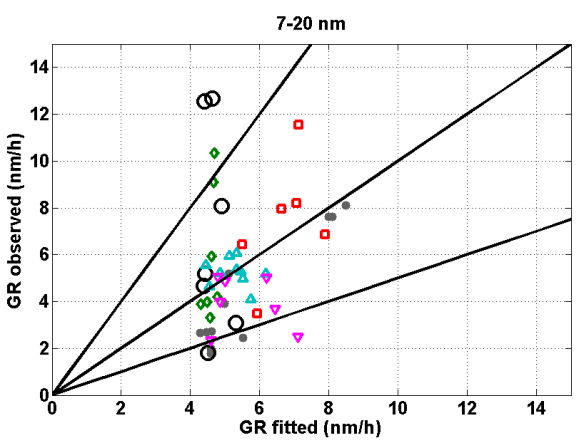

- Hyytiäla

口 Melpitz

O Finokalia

$\triangle$ K-Puzsta

- Hohenpeissenberg

$\nabla$ Vavihill

Fig. A1. Comparison of the observed monthly median growth rates from the EUCAARI stations and those reproduced by the parameterization (see Table 4 for the parameters) for $1.5-3 \mathrm{~nm}, 3-7 \mathrm{~nm}$ and $7-20 \mathrm{~nm}$ particles. The data are the same as in Fig. 6.

where $k_{\mathrm{B}}$ is Boltzmann constant, $T$ is temperature, $\mu$ is dynamic viscosity of the air, and $C_{\mathrm{c}}$ is Cunningham slip correction factor that is determined from the relation between the dimension of the particle and air molecules. $C_{\mathrm{c}}$ can be determined using the following expression:

$C_{\mathrm{c}}=1+\frac{2 \lambda}{d_{\mathrm{p}}}\left(1.257+0.4 \exp \left(-\frac{1.1 d_{\mathrm{p}}}{2 \lambda}\right)\right)$,

where $\lambda$ is the mean free path of an air molecule and the numerical coefficients are obtained from Allen and Raabe (1982).

Mean thermal speed of a vapor molecule (molar mass $M_{\mathrm{v}}$ ) is

$\overline{c_{\mathrm{v}}}=\sqrt{\frac{8 R T}{\pi M_{\mathrm{v}}},}$ where $R$ is gas constant. Mean thermal speed of a particle (mass $m_{\mathrm{p}}$ ) is

$\overline{c_{\mathrm{p}}}=\sqrt{\frac{8 k_{\mathrm{B}} T}{\pi m_{\mathrm{p}}}}$.

Acknowledgements. This work was financially supported by the University of Helsinki three-year research grant (No. 490082), by Maj and Tor Nessling Foundation (No. 2010143), Academy of Finland (No. 139656), Finnish Center of Excellence grant (No. 1118615), European Research Council grants ATMNUCLE (No. 227463) and ATMOGAIN (No. 278277), European Integrated project PEGASOS (FP7-ENV-2010-265148), and Finnish Academy of Science and Letters (Vilho, Yrjö and Kalle Väisälä Foundation), which are gratefully acknowledged.

Edited by: A. Hofzumahaus

\section{References}

Aalto, P., Hämeri, K., Becker, E., Weber, R., Salm, J., Mäkelä, J. M., Hoell, C., O’Dowd, C. D., Karlsson, H.-C., Väkevä, M., Koponen, I. K., Buzorius, G., and Kulmala, M.: Physical characterization of aerosol particles during nucleation events, Tellus B, 53, 344-358, 2001.

Allen, M. D. and Raabe, O. G.: Reevaluation of Millikan's oil drop data for the motion of small particles in air, J. Aerosol Sci., 13, 537-547, 1982.

Berndt, T., Stratmann, F., Sipilä, M., Vanhanen, J., Petäjä, T., Mikkilä, J., Grüner, A., Spindler, G., Lee Mauldin III, R., Curtius, J., Kulmala, M., and Heintzenberg, J.: Laboratory study on new particle formation from the reaction $\mathrm{OH}+\mathrm{SO}_{2}$ : influence of experimental conditions, $\mathrm{H}_{2} \mathrm{O}$ vapour, $\mathrm{NH}_{3}$ and the amine tert-butylamine on the overall process, Atmos. Chem. Phys., 10, 7101-7116, doi:10.5194/acp-10-7101-2010, 2010.

Bohren, C. F. and Huffman, D. R.: Absorption and Scattering of Light by Small Particles, John Wiley \& Sons, New York, 1983.

Boy, M., Kulmala, M., Ruuskanen, T. M., Pihlatie, M., Reissell, A., Aalto, P. P., Keronen, P., Dal Maso, M., Hellen, H., Hakola, H., Jansson, R., Hanke, M., and Arnold, F.: Sulphuric acid closure and contribution to nucleation mode particle growth, Atmos. Chem. Phys., 5, 863-878, doi:10.5194/acp-5-863-2005, 2005.

Cabada, J. C., Khlystov, A., Wittig, A. E., Pilinis, C., and Pandis, S. N.: Light scattering by fine particles during the Pittsburgh Air Quality Study: Measurements and modeling, J. Geophys. Res., 109, D16S03, doi:10.1029/2003JD004155, 2004.

Dal Maso, M., Kulmala M., Riipinen, I., Wagner, R., Hussein, T., Aalto, P. P., and Lehtinen, K. E. J.: Formation and growth of fresh atmospheric aerosols: eight years of aerosol size distribution data from SMEAR II, Hyytiälä, Finland, Boreal Environ. Res., 10, 323-336, 2005.

Donahue, N. M., Trump, E. R., Pierce, J. R., and Riipinen, I.: Theoretical constraints on pure vapor-pressure driven condensation of organics to ultrafine particles, Geophys. Res. Lett., 38, L16801, doi:10.1029/2011GL048115, 2011.

Dusek, U., Frank, G. P., Hildebrandt, L., Curtius, J., Schneider, J., Walter, S., Chand, D., Drewnick, F., Hings, S., Jung, D., Bor- 
rmann, S., and Andreae, M. O.: Size matters more than chemistry for cloud-nucleating ability of aerosol particles, Science, 312, 1375-1378, 2006.

Fuchs, N. A. and Sutugin, A. G.: High dispersed aerosols, in: Topics in Current Aerosol Research (Part 2), edited by: Hidy, G. M. and Brock, J. R., Pergamon, New York, USA, 1-200, 1971.

Goldstein, A. E. and Galbally, I. E.: Known and Unexplored Organic Constituents in the Earth's Atmosphere, Environ. Sci. Technol., 41, 1514-1521, 2007.

Guenther, A., Hewitt, C. N., Erickson, D., Fall, R., Geron, C., Graedel, T., Harley, P., Klinger, L., Lerdau, M., McKay, W. A., Pierce, T., Scholes, B., Steinbrecher, R., Tallamraju, R., Taylor, J., and Zimmermann, P.: A global model of natural volatile organic compound emissions, J. Geophys. Res., 100, 8873-8892, 1995.

Hakola, H, Tarvainen, V., Laurila, T., Hiltunen, V., Hellen, H., and Keronen, P.: Seasonal variation of VOC concentrations above a boreal coniferous forest, Atmos. Environ., 37, 1623-1634, 2003.

Hallquist, M., Wenger, J. C., Baltensperger, U., Rudich, Y., Simpson, D., Claeys, M., Dommen, J., Donahue, N. M., George, C., Goldstein, A. H., Hamilton, J. F., Herrmann, H., Hoffmann, T., Iinuma, Y., Jang, M., Jenkin, M. E., Jimenez, J. L., KiendlerScharr, A., Maenhaut, W., McFiggans, G., Mentel, Th. F., Monod, A., Prévôt, A. S. H., Seinfeld, J. H., Surratt, J. D., Szmigielski, R., and Wildt, J.: The formation, properties and impact of secondary organic aerosol: current and emerging issues, Atmos. Chem. Phys., 9, 5155-5236, doi:10.5194/acp-9-51552009, 2009.

Hari, P. and Kulmala, M.: Station for Measuring EcosystemAtmosphere Relations (SMEAR II), Boreal Env. Res., 10, 315322, 2005.

Heald, C. L., Coe, H., Jimenez, J. L., Weber, R. J., Bahreini, R., Middlebrook, A. M., Russell, L. M., Jolleys, M., Fu, T.-M., Allan, J. D., Bower, K. N., Capes, G., Crosier, J., Morgan, W. T., Robinson, N. H., Williams, P. I., Cubison, M. J., DeCarlo, P. F., and Dunlea, E. J.: Exploring the vertical profile of atmospheric organic aerosol: comparing 17 aircraft field campaigns with a global model, Atmos. Chem. Phys., 11, 12673-12696, doi:10.5194/acp-11-12673-2011, 2011.

Hirsikko, A., Laakso, L., Hõrrak, U., Aalto, P. P., Kerminen, V.M., and Kulmala, M.: Annual and size dependent variation of growth rates and ion concentrations in boreal forest, Boreal Environ. Res., 10, 357-369, 2005.

Hoyle, C. R., Boy, M., Donahue, N. M., Fry, J. L., Glasius, M., Guenther, A., Hallar, A. G., Huff Hartz, K., Petters, M. D., Petäjä, T., Rosenoern, T., and Sullivan, A. P.: A review of the anthropogenic influence on biogenic secondary organic aerosol, Atmos. Chem. Phys., 11, 321-343, doi:10.5194/acp-11-321-2011, 2011.

Iida, K., Stolzenburg, M. R., McMurry, P. H., and Smith, J. N.: Estimating nanoparticle growth rates from size-dependent charged fractions: Analysis of the new particle formation events in Mexico City, J. Geophys. Res., 113, D05207, doi:10.1029/2007JD009260, 2008.

Kanakidou, M., Seinfeld, J. H., Pandis, S. N., Barnes, I., Dentener, F. J., Facchini, M. C., Van Dingenen, R., Ervens, B., Nenes, A., Nielsen, C. J., Swietlicki, E., Putaud, J. P., Balkanski, Y., Fuzzi, S., Horth, J., Moortgat, G. K., Winterhalter, R., Myhre, C. E. L., Tsigaridis, K., Vignati, E., Stephanou, E. G., and Wilson, J.: Organic aerosol and global climate modelling: a review, At- mos. Chem. Phys., 5, 1053-1123, doi:10.5194/acp-5-1053-2005, 2005.

Kerminen, V.-M. and Kulmala, M.: Analytical formulae connecting the "real" and the "apparent" nucleation rate and the nuclei number concentration for atmospheric nucleation events, J. Aerosol Sci., 33, 609-622, 2002.

Kerminen, V.-M., Paramonov, M., Anttila, T., Riipinen, I., Fountoukis, C., Korhonen, H., Asmi, E., Laakso, L., Lihavainen, H., Swietlicki, E., Svenningsson, B., Asmi, A., Pandis, S. N., Kulmala, M., and Petäjä, T.: Cloud condensation nuclei production associated with atmospheric nucleation: a synthesis based on existing literature and new results, Atmos. Chem. Phys., 12, 1203712059, doi:10.5194/acp-12-12037-2012, 2012.

Kirkby, J., Curtius, J., Almeida, J., Dunne, E., Duplissy, J., Ehrhart, S., Franchin, A., Gagné, S., Ickes, L., Kurten, A., Kupc, A., Metzger, A., Riccobono, F., Rondo, L., Schobesberger, S., Tsagkogeorgas, G., Wimmer, D., Amorim, A., Bianchi, F., Breitenlechner, M., David, A., Dommen, J., Downard, A., Ehn, M., Flagan, R. C., Haider, S., Hansel, A., Hauser, D., Jud, W., Junninen, H., Kreissl, F., Kvashin, A., Laaksonen, A., Lehtipalo, K., Lima, J., Lovejoy, E. R., Makhmutov, V., Mathot, S., Mikkilä, J., Minginette, P., Mogo, S., Nieminen, T., Onnela, A., Pereira, P., Petäjä, T., Schnitzhofer, R., Seinfeld, J. H., Sipilä, M., Stozhkov, Y., Stratmann, F., Tome, A., Vanhanen, J., Viisanen, Y., Vrtala, A., Wagner, P. E., Walther, H., Weingartner, E., Wex, H., Winkler, P. M., Carslaw, K. S., Worsnop, D. R., Baltensperger, U., and Kulmala, M.: Role of sulphuric acid, ammonia and galactic cosmic rays in atmospheric aerosol nucleation, Nature, 476, 429-433, doi:10.1038/nature10343, 2011.

Kuang, C., McMurry, P. H., McCormick, A. V., and Eisele, F. L.: Dependence of nucleation rates on sulfuric acid vapor concentration in diverse atmospheric locations, J. Geophys. Res., 113, D10209, doi:10.1029/2007JD009253, 2008.

Kuang, C., McMurry, P. H., and McCormick, A. V.: Determination of cloud condensation nuclei production from measured new particle formation events, Geophys. Res. Lett., 36, L09822, doi:10.1029/2009GL037584, 2009.

Kuang, C., Riipinen, I., Sihto, S.-L., Kulmala, M., McCormick, A. V., and McMurry, P. H.: An improved criterion for new particle formation in diverse atmospheric environments, Atmos. Chem. Phys., 10, 8469-8480, doi:10.5194/acp-10-84692010, 2010.

Kuang, C., Chen, M., Zhao, J., Smith, J., McMurry, P. H., and Wang, J.: Size and time-resolved growth rate measurements of 1 to $5 \mathrm{~nm}$ freshly formed atmospheric nuclei, Atmos. Chem. Phys., 12, 3573-3589, doi:10.5194/acp-12-3573-2012, 2012.

Kulmala, M. and Kerminen, V. M.: On the formation and growth of atmospheric nanoparticles, Atmos. Res., 90, 132-150, 2008.

Kulmala, M. and Laaksonen, A.: Binary nucleation of water- sulfuric acid system: Comparison of classical theories with different H2SO4 saturation vapor pressures, J. Chem. Phys., 93, 696-701, 1990.

Kulmala, M., Toivonen, A., Mäkelä, J. M., and Laaksonen, A.: Analysis of the growth of nucleation mode particles observed in boreal forest, Tellus B, 50, 449-462, 1998.

Kulmala, M., Hämeri, K., Aalto, P. P., Mäkelä, J. M., Pirjola, L., Nilsson, E. D., Buzorius, G., Rannik, Ü., Dal Maso, M., Seidl, W., Hoffmann, T., Janson, R., Hansson, H.-C., Viisanen, Y., Laaksonen, A., and O'Dowd, C. D.: Overview of the interna- 
tional project on biogenic aerosol formation in the boreal forest (BIOFOR), Tellus B, 53, 324-343, 2001a.

Kulmala, M., Dal Maso, M., Mäkelä, J. M., Pirjola, L., Väkevä, M., Aalto, P., Miikkulainen, P., Hämeri, K., and O’Dowd, C. D.: On the formation, growth and composition of nucleation mode particles, Tellus B, 53, 479-490, 2001b.

Kulmala, M., Vehkamäki, H., Petäjä, T., Dal Maso, M., Lauri, A., Kerminen, V.-M., Birmili, W., and McMurry, P. H.: Formation and growth rates of ultrafine atmospheric particles: a review of observations, J. Aerosol Sci., 35, 143-176, 2004.

Kulmala, M., Asmi, A., Lappalainen, H. K., Baltensperger, U., Brenguier, J.-L., Facchini, M. C., Hansson, H.-C., Hov, Ø., O'Dowd, C. D., Pöschl, U., Wiedensohler, A., Boers, R., Boucher, O., de Leeuw, G., Denier van der Gon, H. A. C., Feichter, J., Krejci, R., Laj, P., Lihavainen, H., Lohmann, U., McFiggans, G., Mentel, T., Pilinis, C., Riipinen, I., Schulz, M., Stohl, A., Swietlicki, E., Vignati, E., Alves, C., Amann, M., Ammann, M., Arabas, S., Artaxo, P., Baars, H., Beddows, D. C. S., Bergström, R., Beukes, J. P., Bilde, M., Burkhart, J. F., Canonaco, F., Clegg, S. L., Coe, H., Crumeyrolle, S., D’ Anna, B., Decesari, S., Gilardoni, S., Fischer, M., Fjaeraa, A. M., Fountoukis, C., George, C., Gomes, L., Halloran, P., Hamburger, T., Harrison, R. M., Herrmann, H., Hoffmann, T., Hoose, C., Hu, M., Hyvärinen, A., Hõrrak, U., Iinuma, Y., Iversen, T., Josipovic, M., Kanakidou, M., Kiendler-Scharr, A., Kirkevåg, A., Kiss, G., Klimont, Z., Kolmonen, P., Komppula, M., Kristjánsson, J.E., Laakso, L., Laaksonen, A., Labonnote, L., Lanz, V. A., Lehtinen, K. E. J., Rizzo, L. V., Makkonen, R., Manninen, H. E., McMeeking, G., Merikanto, J., Minikin, A., Mirme, S., Morgan, W. T., Nemitz, E., O’Donnell, D., Panwar, T. S., Pawlowska, H., Petzold, A., Pienaar, J. J., Pio, C., Plass-Duelmer, C., Prévôt, A. S. H., Pryor, S., Reddington, C. L., Roberts, G., Rosenfeld, D., Schwarz, J., Seland, Ø., Sellegri, K., Shen, X. J., Shiraiwa, M., Siebert, H., Sierau, B., Simpson, D., Sun, J. Y., Topping, D., Tunved, P., Vaattovaara, P., Vakkari, V., Veefkind, J. P., Visschedijk, A., Vuollekoski, H., Vuolo, R., Wehner, B., Wildt, J., Woodward, S., Worsnop, D. R., van Zadelhoff, G.-J., Zardini, A. A., Zhang, K., van Zyl, P. G., Kerminen, V.-M., Carslaw, K. S., and Pandis, S. N.: General overview: European Integrated project on Aerosol Cloud Climate and Air Quality interactions (EUCAARI) - integrating aerosol research from nano to global scales, Atmos. Chem. Phys., 11, 1306113143, doi:10.5194/acp-11-13061-2011, 2011.

Kulmala, M., Kontkanen, J., Junninen, H., Lehtipalo, K., Manninen, H. E., Nieminen, T., Petäjä, T., Sipilä, M., Schobesberger, S., Rantala, P., Franchin, A., Jokinen, T., Järvinen, E., Äijälä, M., Kangasluoma, J., Hakala, J., Aalto, P. P., Paasonen, P., Mikkilä, J., Vanhanen, J., Aalto, J., Hakola, H., Makkonen, U., Ruuskanen, T., Mauldin III, R. L., Duplissy, J., Vehkamäki, H., Bäck, J., Kortelainen, A., Riipinen, I., Kurtén, T., Johnston, M. V., Smith, J. N., Ehn, M., Mentel, T. F., Lehtinen, K. E. J., Laaksonen, A., Kerminen, V.-M., and Worsnop, D. R.: Direct observations of atmospheric aerosol nucleation, Science, 339, 943-946, 2013.

Lappalainen, H. K., Sevanto, S., Bäck, J., Ruuskanen, T. M., Kolari, P., Taipale, R., Rinne, J., Kulmala, M., and Hari, P.: Daytime concentrations of biogenic volatile organic compounds in a boreal forest canopy and their relation to environmental and biological factors, Atmos. Chem. Phys., 9, 5447-5459, doi:10.5194/acp-9-5447-2009, 2009.
Lehtinen, K. E. J. and Kulmala, M.: A model for particle formation and growth in the atmosphere with molecular resolution in size, Atmos. Chem. Phys., 3, 251-257, doi:10.5194/acp-3-251-2003, 2003.

Leppä, J., Anttila, T., Kerminen, V.-M., Kulmala, M., and Lehtinen, K. E. J.: Atmospheric new particle formation: real and apparent growth of neutral and charged particles, Atmos. Chem. Phys., 11, 4939-4955, doi:10.5194/acp-11-4939-2011, 2011.

Leppä, J., Gagné, S., Laakso, L., Manninen, H. E., Lehtinen, K. E. J., Kulmala, M., and Kerminen, V.-M.: Using measurements of the aerosol charging state in determination of the particle growth rate and the proportion of ion-induced nucleation, Atmos. Chem. Phys., 13, 463-486, doi:10.5194/acp-13-463-2013, 2013.

Liao, L., Dal Maso, M., Taipale, R., Rinne, J., Ehn, M., Junninen, H., Äijälä, M., Nieminen, T., Alekseychik, P., Hulkkonen, M., Worsnop, D. R., Kerminen, V.-M., and Kulmala, M.: Monoterpene pollution episodes in a forest environment: indication of anthropogenic origin and association with aerosol particles, Boreal Env. Res., 16, 288-303, 2011.

Lindinger, W., Hansel, A., and Jordan, A.: Proton-transfer-reaction mass spectrometry (PTR-MS): on-line monitoring of volatile organic compounds at ppt levels, Chem. Soc. Rev., 27, 347-354, 1998.

Makkonen, R., Asmi, A., Kerminen, V.-M., Boy, M., Arneth, A., Guenther, A., and Kulmala, M.: BVOC-aerosol-climate interactions in the global aerosol-climate model ECHAM5.5-HAM2, Atmos. Chem. Phys., 12, 10077-10096, doi:10.5194/acp-1210077-2012, 2012.

Manninen, H. E., Nieminen, T., Asmi, E., Gagné, S., Häkkinen, S., Lehtipalo, K., Aalto, P., Vana, M., Mirme, A., Mirme, S., Hõrrak, U., Plass-Dülmer, C., Stange, G., Kiss, G., Hoffer, A., Töroe, N., Moerman, M., Henzing, B., de Leeuw, G., Brinkenberg, M., Kouvarakis, G. N., Bougiatioti, A., Mihalopoulos, N., O'Dowd, C., Ceburnis, D., Arneth, A., Svenningsson, B., Swietlicki, E., Tarozzi, L., Decesari, S., Facchini, M. C., Birmili, W., Sonntag, A., Wiedensohler, A., Boulon, J., Sellegri, K., Laj, P., Gysel, M., Bukowiecki, N., Weingartner, E., Wehrle, G., Laaksonen, A., Hamed, A., Joutsensaari, J., Petäjä, T., Kerminen, V.-M., and Kulmala, M.: EUCAARI ion spectrometer measurements at 12 European sites - analysis of new-particle formation events, Atmos. Chem. Phys., 10, 7907-7927, 2010, http://www.atmos-chem-phys.net/10/7907/2010/.

Merikanto, J., Spracklen, D. V., Mann, G. W., Pickering, S. J., and Carslaw, K. S.: Impact of nucleation on global CCN, Atmos. Chem. Phys., 9, 8601-8616, 2009, http://www.atmos-chem-phys.net/9/8601/2009/.

Mirme, A., Tamm, E., Mordas, G., Vana, M., Uin, J., Mirme, S., Bernotas, T., Laakso, L., Hirsikko, A., and Kulmala, M.: A widerange multi-channel Air Ion Spectrometer, Boreal Environ. Res., 12, 247-264, 2007.

Nel, A.: Air Pollution-Related Illness: Effects of Particles, Science, 308, 804-806, 2005.

Nieminen, T., Lehtinen, K. E. J., and Kulmala, M.: Sub-10 nm particle growth by vapor condensation - effects of vapor molecule size and particle thermal speed, Atmos. Chem. Phys., 10, 97739779, doi:10.5194/acp-10-9773-2010, 2010.

O’Dowd, C. D., Jimenez, J. L., Bahreini, R., Flagan, R. C., Seinfeld, J. H., Hameri, K., Pirjola, L., Kulmala, M., Jennings, S. G., and 
Hoffmann, T.: Marine aerosol formation from biogenic iodine emissions, Nature, 417, 632-636, 2002.

Petäjä, T., Mauldin, III, R. L., Kosciuch, E., McGrath, J., Nieminen, T., Paasonen, P., Boy, M., Adamov, A., Kotiaho, T., and Kulmala, M.: Sulfuric acid and $\mathrm{OH}$ concentrations in a boreal forest site, Atmos. Chem. Phys., 9, 7435-7448, doi:10.5194/acp9-7435-2009, 2009.

Pierce, J. R. and Adams, P. J.: Efficiency of cloud condensation nuclei formation from ultrafine particles, Atmos. Chem. Phys., 7, 1367-1379, doi:10.5194/acp-7-1367-2007, 2007.

Pierce, J. R. and Adams, P. J.: Uncertainty in global CCN concentrations from uncertain aerosol nucleation and primary emission rates, Atmos. Chem. Phys., 9, 1339-1356, doi:10.5194/acp-91339-2009, 2009.

Pierce, J. R., Riipinen, I., Kulmala, M., Ehn, M., Petäjä, T., Junninen, H., Worsnop, D. R., and Donahue, N. M.: Quantification of the volatility of secondary organic compounds in ultrafine particles during nucleation events, Atmos. Chem. Phys., 11, 90199036, doi:10.5194/acp-11-9019-2011, 2011.

Pierce, J. R., Leaitch, W. R., Liggio, J., Westervelt, D. M., Wainwright, C. D., Abbatt, J. P. D., Ahlm, L., Al-Basheer, W., Cziczo, D. J., Hayden, K. L., Lee, A. K. Y., Li, S.-M., Russell, L. M., Sjostedt, S. J., Strawbridge, K. B., Travis, M., Vlasenko, A., Wentzell, J. J. B., Wiebe, H. A., Wong, J. P. S., and Macdonald, A. M.: Nucleation and condensational growth to $\mathrm{CCN}$ sizes during a sustained pristine biogenic SOA event in a forested mountain valley, Atmos. Chem. Phys., 12, 3147-3163, doi:10.5194/acp-12-3147-2012, 2012.

Pierce, J. R., Evans, M. J., Scott, C. E., D’Andrea, S. D., Farmer, D. K., Swietlicki, E., and Spracklen, D. V.: Weak global sensitivity of cloud condensation nuclei and the aerosol indirect effect to Criegee $+\mathrm{SO}_{2}$ chemistry, Atmos. Chem. Phys., 13, 3163-3176, doi:10.5194/acp-13-3163-2013, 2013.

Poling, B. E., Prausnitz, J. M., and O'Connell, J. P.: The properties of gases and liquids, 5th edn., McGraw-Hill, New York, USA, 2001.

Ramanathan, V., Crutzen, P. J., Kiehl, J. T., and Rosenfeld, D.: Aerosol, climate, and the hydrological cycle, Science, 294, 2119-2124, 2001.

Riipinen, I., Sihto, S.-L., Kulmala, M., Arnold, F., Dal Maso, M., Birmili, W., Saarnio, K., Teinilä, K., Kerminen, V.-M., Laaksonen, A., and Lehtinen, K. E. J.: Connections between atmospheric sulphuric acid and new particle formation during QUEST III-IV campaigns in Heidelberg and Hyytiälä, Atmos. Chem. Phys., 7, 1899-1914, doi:10.5194/acp-7-1899-2007, 2007.

Riipinen, I., Pierce, J. R., Yli-Juuti, T., Nieminen, T., Häkkinen, S., Ehn, M., Junninen, H., Lehtipalo, K., Petäjä, T., Slowik, J., Chang, R., Shantz, N. C., Abbatt, J., Leaitch, W. R., Kerminen, V.-M., Worsnop, D. R., Pandis, S. N., Donahue, N. M., and Kulmala, M.: Organic condensation: a vital link connecting aerosol formation to cloud condensation nuclei $(\mathrm{CCN})$ concentrations, Atmos. Chem. Phys., 11, 3865-3878, doi:10.5194/acp-11-38652011, 2011.

Riipinen, I., Yli-Juuti, T., Pierce, J. R., Petäjä, T., Worsnop, D. R., Kulmala, M., and Donahue, N. M.: The contribution of organics to atmospheric nanoparticle growth, Nature Geosci., 5, 453-458, doi:10.1038/ngeo1499, 2012.

Rosenfeld, D., Lohmann, U., Raga, G. B., O’Dowd, C. D., Kulmala, M., Fuzzi, S., Reissell, A., and Andreae, M. O.: Flood or
Drought: How Do Aerosols Affect Precipitation?, Science, 312, 1309-1313, 2008.

Sihto, S.-L., Kulmala, M., Kerminen, V.-M., Dal Maso, M., Petäjä, T., Riipinen, I., Korhonen, H., Arnold, F., Janson, R., Boy, M., Laaksonen, A., and Lehtinen, K. E. J.: Atmospheric sulphuric acid and aerosol formation: implications from atmospheric measurements for nucleation and early growth mechanisms, Atmos. Chem. Phys., 6, 4079-4091, doi:10.5194/acp-64079-2006, 2006.

Sipilä, M., Berndt, T., Petäjä, T., Brus, D., Vanhanen, J., Stratmann, F., Patokoski, J., Mauldin, R. L., Hyvärinen, A. P., Lihavainen, H., and Kulmala, M.: The role of sulfuric acid in atmospheric nucleation, Science, 327, 1243-1246, doi:10.1126/science.1180315, 2010.

Smith, J. N., Moore, K. F., Eisele, F. L., Voisin, D., Ghimire, A. K., Sakurai, H., and McMurry, P. H.: Chemical composition of atmospheric nanoparticles during nucleation events in Atlanta, J. Geophys. Res., 110, D22S03, doi:10.1029/2005JD005912, 2005.

Smith, J. N., Dunn, M. J., Vanreken, T. M., Iida, K., Stolzenburg, M. R., McMurry, P. H., and Huey, L. G.: Chemical composition of atmospheric nanoparticles formed from nucleation in Tecamac, Mexico: Evidence for an important role for organic species in nanoparticle growth, Geophys. Res. Lett., 35, L04808, doi:10.1029/2007GL032523, 2008.

Spracklen, D. V., Pringle, K. J., Carslaw, K. S., Chipperfield, M. P., and Mann, G. W.: A global off-line model of size-resolved aerosol microphysics: I. Model development and prediction of aerosol properties, Atmos. Chem. Phys., 5, 2227-2252, doi:10.5194/acp-5-2227-2005, 2005a.

Spracklen, D. V., Pringle, K. J., Carslaw, K. S., Chipperfield, M. P., and Mann, G. W.: A global off-line model of size-resolved aerosol microphysics: II. Identification of key uncertainties, Atmos. Chem. Phys., 5, 3233-3250, doi:10.5194/acp-5-3233-2005, 2005b.

Spracklen, D. V., Carslaw, K. S., Kulmala, M., Kerminen, V.-M., Mann, G. W., and Sihto, S.-L.: The contribution of boundary layer nucleation events to total particle concentrations on regional and global scales, Atmos. Chem. Phys., 6, 5631-5648, doi:10.5194/acp-6-5631-2006, 2006.

Spracklen, D., Carslaw, K., Kulmala, M., Kerminen, V.-M., Sihto, S.-L., Riipinen, I., Merikanto, J., Mann, G., Chipperfield, M., Wiedensohler, A., Birmili, W., and Lihavainen, H.: Contribution of particle formation to global cloud condensation nuclei concentrations, Geophys. Res. Lett., 35, L06808, doi:10.1029/2007GL033038, 2008.

Spracklen, D. V., Jimenez, J. L., Carslaw, K. S., Worsnop, D. R., Evans, M. J., Mann, G. W., Zhang, Q., Canagaratna, M. R., Allan, J., Coe, H., McFiggans, G., Rap, A., and Forster, P.: Aerosol mass spectrometer constraint on the global secondary organic aerosol budget, Atmos. Chem. Phys., 11, 12109-12136, doi:10.5194/acp-11-12109-2011, 2011.

Stolzenburg, M. R., McMurry, P. H., Sakurai, H., Smith, J. N., Mauldin III, R. L., Eisele, F. L., and Clement, C. F.: Growth rates of freshly nucleated atmospheric particles in Atlanta, J. Geophys. Res., 110, D22S05, doi:10.1029/2005JD005935, 2005.

Tammet, H.: Continuous scanning of the mobility and size distribution of charged cluster and nanometer particles in atmospheric air and the Balanced Scanning Mobility Analyzer BSMA, Atmos. Res., 82, 523-535, 2006. 
Vehkamäki, H. and Riipinen, I.: Thermodynamics and kinetics of atmospheric aerosol particle formation and growth, Chem. Soc. Rev., 41, 5160-5173, doi:10.1039/C2CS00002D, 2012.

Vesala, T., Haataja, J., Aalto, P., Altimir, N., Buzorius, G., Garam, E., Hämeri, K., Ilvesniemi, H., Jokinen, V., Keronen, P., Lahti, T., Markkanen, T., Mäkelä, J., Nikinmaa, E., Palmroth, S., Palva, L., Pohja, T., Pumpanen, J., Rannik, U., Siivola, E., Ylitalo, H., Hari, P., and Kulmala, M.: Long-term field measurements of atmosphere-surface interactions in boreal forest combining forest ecology, micrometeorology, aerosol physics and atmospheric chemistry, Trends Heat, Mass Mom. Trans., 4, 17-35, 1998.

Volkamer, R., Jimenez, J. L., San Martini, F., Dzepina, K., Zhang, Q., Salcedo, D., Molina, L. T., Worsnop, D. R., and Molina, M. J.: Secondary organic aerosol formation from anthropogenic air pollution: Rapid and higher than expected, Geophys. Res. Lett., 33, L17811, doi:10.1029/2006GL026899, 2006.

Weber, R. J., Marti, J. J., McMurry, P. H., Eisele, F. L., Tanner, T. J., and Jefferson, A.: Measured atmospheric new particle formation rates: Implications for nucleation mechanisms, Chem. Eng. Commun., 151, 53-64, 1996.

Yli-Juuti, T., Nieminen, T., Hirsikko, A., Aalto, P. P., Asmi, E., Hõrrak, U., Manninen, H. E., Patokoski, J., Dal Maso, M., Petäjä, T., Rinne, J., Kulmala, M., and Riipinen, I.: Growth rates of nucleation mode particles in Hyytiälä during 2003-2009: variation with particle size, season, data analysis method and ambient conditions, Atmos. Chem. Phys., 11, 12865-12886, doi:10.5194/acp-11-12865-2011, 2011.
Yu, F. and Luo, G.: Simulation of particle size distribution with a global aerosol model: Contribution of nucleation to aerosol and CCN number concentrations, Atmos. Chem. Phys., 9, 76917710, 2009, http://www.atmos-chem-phys.net/9/7691/2009/.

$\mathrm{Yu}, \mathrm{H}$., McGraw, R., and Lee, S. H.: Effects of amines on formation of sub-3 nm particles and their subsequent growth, Geophys. Res. Lett., 39, L02807, doi:10.1029/2011GL050099, 2012.

Zhang, Q., Jimenez, J. L., Canagaratna, M. R., Allan, J. D., Coe, H., Ulbrich, I., Alfarra, M. R., Takami, A., Middlebrook, A. M., Sun, Y. L., Dzepina, K., Dunlea, E., Docherty, K., DeCarlo, P. F., Salcedo, D., Onasch, T., Jayne, J. T., Miyoshi, T., Shimono, A., Hatakeyama, S., Takegawa, N., Kondo, Y., Schneider, J., Drewnick, F., Weimer, S., Demerjian, K., Williams, P., Bower, K., Bahreini, R., Cotrell, L., Griffin, R. J., Rautiainen, J., Sun, J. Y., Zhang, Y. M., and Worsnop, D. R.: Ubiquity and dominance of oxygenated species in organic aerosols in anthropogenicallyinfluenced Northern Hemisphere mid-latitudes, Geophys. Res. Lett., 34, L13801, doi:10.1029/2007GL029979, 2007.

Zhang, R., Khalizov, A. Wang, L. Hu, M., and Xu, W: Nucleation and growth of nanoparticles in the atmosphere, Chem. Rev., 112, 1957-2011, 2012a.

Zhang, X., Pandis, S. N., and Seinfeld, J. H.: Diffusion-Limited Versus Quasi-Equilibrium Aerosol Growth, Aerosol Sci. Technol., 46, 874-885, 2012b. 